\title{
EFFCT USING THE REFLECTIVE TEACHING ON THE CLASSROOM PREFORMANCE OF STUDENT TEACHERS MAJORING IN ENGLISH AND THEIR ATTITUDES TOWARDS IT
}

\author{
BY \\ Hashemah Ali Alhazmi \\ Lecturer at Jazan University
}

Doi: 10.12816/0049772

مجلة الدراسات التربوية والانسانية ـ كلية التربية ـ جامعة دمنهور المجلد التاسع - العدد الثانى - لسنة 2017 
مجلة الدراسات التربوية والانسانية ـ كلية التربية ـ جامعة دمنهور. المجلد التاسع - العدد الثانى - لسنة2017م 


\begin{abstract}
This study aimed at investigating the effect of the reflective teaching on the classroom performance of English Major student teachers and their attitudes towards it. The main purpose of the study was to develop student teacher's classroom performance by using reflective teaching. The pretestposttest equivalent groups design was adopted. Sample of the study consisted of $(n=32)$ English Major student teachers, enrolled at Girls' College of Education - Jazan. Subjects were randomly assigned to two groups (control and experimental). The control group received only the traditional supervisory practices while the experimental group was trained in using the reflective approach and introduced to three different activities of reflection which were journal writing, peer observation, and five-minute papers. Research instruments were checklist of classroom teaching practices, analytic scoring rubric, workshop "becoming a critically reflective EFL teacher", and questionnaire on reflective teaching practices. Data collected were statistically analyzed qualitatively and quantitatively. Descriptive statistics (mean, standard deviation, frequency, rank and percentage), independent and paired samples ttest (2-tailed) were used for data analysis. The effect size "d" was computed using Eta Squared " $\eta^{2}$ ". Findings of the post-observation showed a noticeable improvement in classroom performance of the experimental group. Statistically significant differences at 0.01 level were found in overall classroom performance and in six cores i. e., giving effective instructions, using motivated question techniques, choosing suitable techniques for correcting mistakes, praising the correct answers, systematic handling of the blackboard, and making and using available audio-visual aids, in favor of the experimental group. Statistically significant differences at 0.01 level were also noted in overall classroom performance and in the six cores of classroom performance of the experimental group, in favor of posttest. Also, there were favorable attitudes among the experimental group towards reflective teaching practices. The study concluded that the reflective teaching approach can be used effectively with student teachers during the practicum period. It was recommended that it should be incorporated in EFL teacher education programs, specifically in EFL methodology course. However, student teachers should make every effort to learn more about a variety of reflective activities. The reflective teaching approach could be used in developing and improving the classroom performance of in-service teachers as well. Prospective teachers should be trained on methods of developing reflective thinking levels.
\end{abstract}

Key Words: Effect, reflective teaching, classroom performance, student teachers, English. 
أثر استخدام التدريس التأملي على الأداء الصفي للطالبات المعلمات تخصص اللغة الإنجليزية واتجاهاتهن نحوه

\section{مستخلص الاراسة}

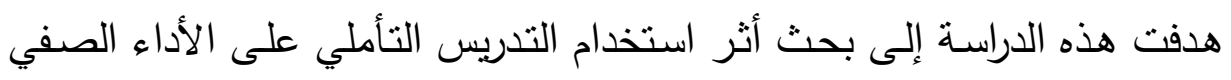

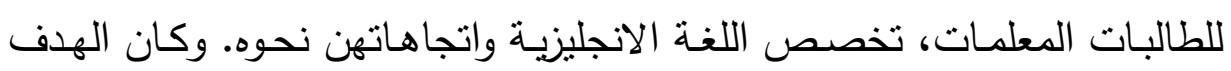

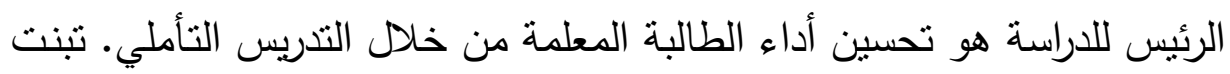

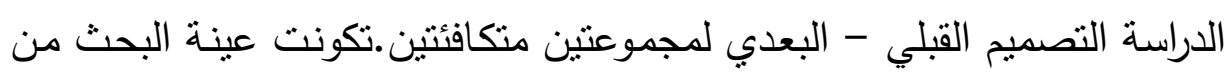
32 طالبة مقيدة بالفرقة الرابعة، تخصص اللغة الإنجليزية، بكلية التربية للبنات

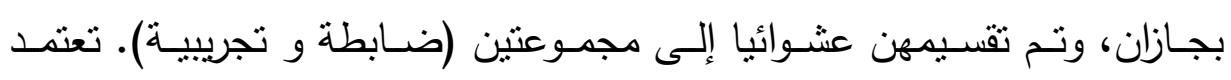

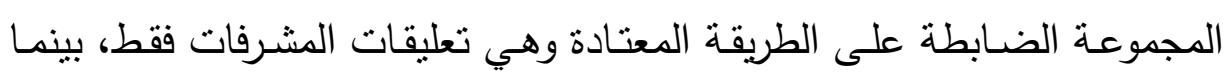

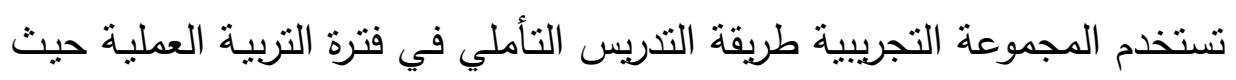
نم تدريب المجموعة التجريبية على استخدام ثلاثة أنشطة للتنريس التأملي وهي :

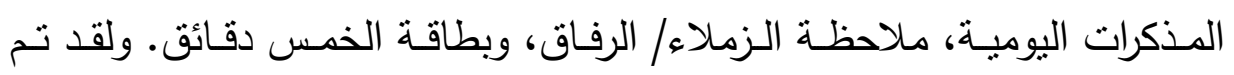

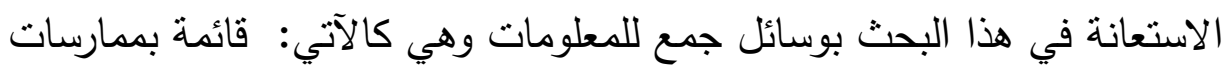

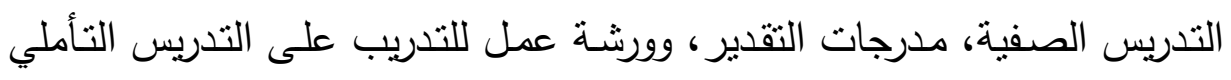
وأنشطته و استبانة ممارسات التدريس التأملي.وتم تحليل البيانات كمياً وكيفياً.

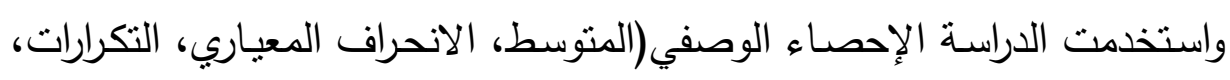
الرتب، والنسبة المئوية)، واختبار ت (عينتين مستقلنتين وعينتين غير مستقلتنين)

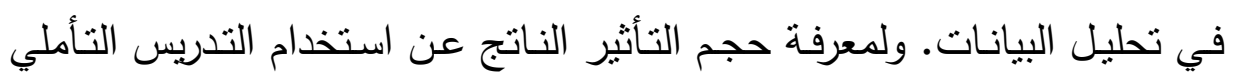

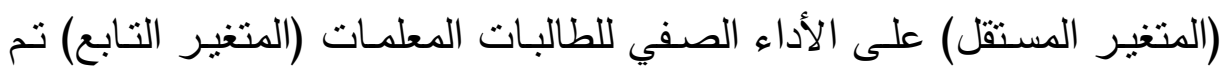

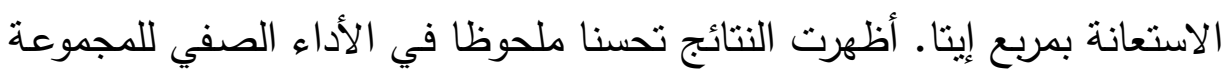

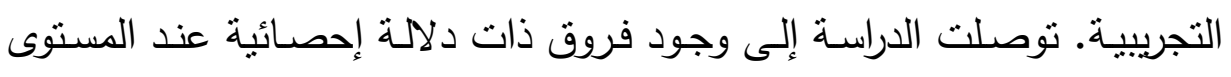
0.0101 لقائهـة معايير الأداء الصفي ككل وفي كل محور من المحساور الستة (توجيـه

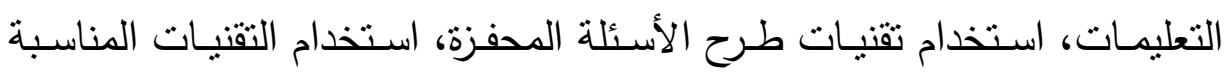

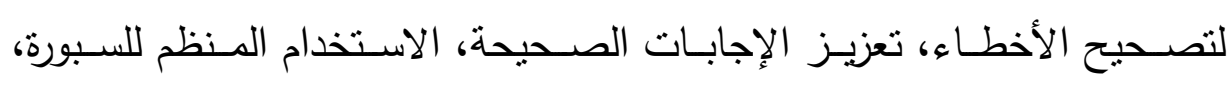
واستخدام مصـادر المعلومـات والوسـائل المتوفرة) لصـالح المجموعـة التجريبيـة. كذلك توصلت الدراسة إلى وجود فروق ذات دلالة إحصائية عند المستوى 0.01 بين منوسط درجات المجموعـة التجريبيـة في النطبيق القبلي و البعدي لقائمـة 
معايير الأداء الصفي ككل وفي كل محور من المحاور الستة السابق ذكرها وذلك الك

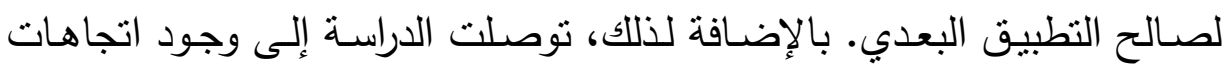
إيجابيـة لدى الطالبات المعلمـات (المجموعـة التجريبية) نحو استخدام الأنشطة

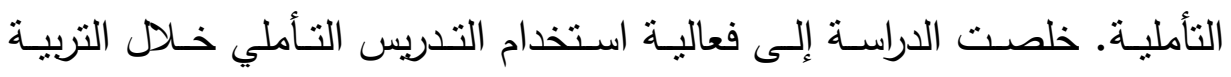
العملية في تحسين الأداء الصفي للطالبات المعلمات. وفي ضواء التهاء النتائج التي تم

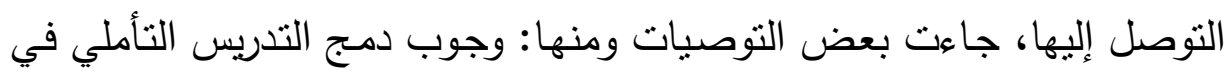

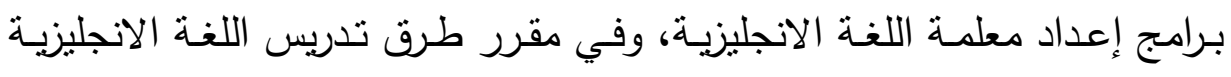

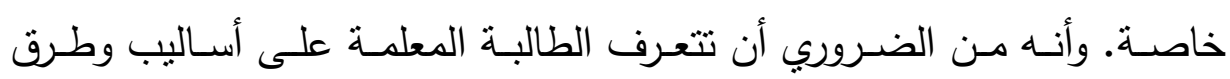
مختلفة ومتعددة للتأمل. وقد أوصت الدراسة بإمكانية تطوير أداء المعلمات أثناء

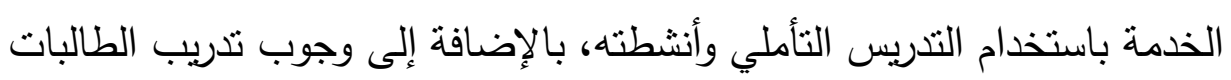
المعلمات على استخدام الأدوات التي تدعم التفكير التأملي.

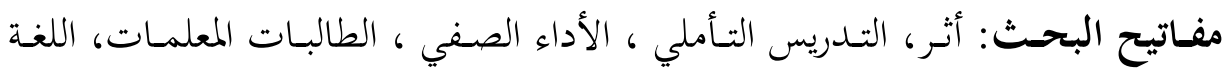
الإنحليزية 
Researches on teaching and teacher education have proved a shift of emphasis to teachers' thought processes. Aly (2004) said that "the important issues in teaching practice are not the ritualistic performance of set routines. (e.g., Has the teacher got a lesson plan? Can the teacher control the class? etc.)" (pp. 155156). Finley, Lawrenz, and Heller (1992) added that studies on teacher education programs "will be of limited value if we do not learn how pre-service students thinking about teaching develops, which of the teaching practices provided in methods courses are actually employed by students, and determine the types of experiences that are important for pre-service teachers as they begin to enter the profession" (p. 302).

The idea of reflection started many years ago. Burge (2004) reported that "the concept of reflection for improving professional practice has gained notable regard in the United Kingdom, Canada, United States, Australia, and other countries throughout the past two decades" (p. 11). "Recent frameworks for reflection build on the theories of Dewey and Schon, and include common process elements that owe a dept to early advocates for reflection" (Ward, 2004, p. 245). The term "reflective teaching" has been widely used in the field of teaching and teacher education. Cruickshank and Applegate (1981) referred to reflective teaching as "helping teachers to think about what happened, why it happened, and what else they could have done to reach their goals" (p. 553).

The important quality of reflection is thinking about practice to improve (Hatton \& Smith, 1995). Different studies and researches have suggested that reflective teaching can lead to professional and personal growth,

\section{Introduction :}

Teachers need to develop and strengthen the qualifications which are necessary to carry out their different functions. For this reason, the pre-service and in-service preparation programs must be updated through which teachers can acquire the necessary and suitable experiences.

One of these preparation programs is the teaching program currently used in the faculties of education. Burden and Williams (1998) and Neisler (2000) confirmed the importance of these programs which would give the student teachers varied abilities such as critical thinking and problem solving. Through these programs student teachers would acquire some facts about the characteristics of a good teacher and teaching. They would learn more about the useful methods of teaching, how to choose and use instructional materials, how to manage the class and how to evaluate their students. Also, student teachers would know the role of school management and system. Bain, Ballantyne, Packer, and Mills (1999) reported that teaching practice experience is the most important aspect of their teacher education program.

It is noticed that there has been a considerable growth of interest in the use of recent trends in teaching English as a foreign language which develop the teachers' performance such as attending conferences, consulting colleagues, discussing published scholarship and participating in teacher development courses. Richards and Lockhart (2005) mentioned that there is a movement away from "methods" and other "external" or "top down" views of teaching towards an "internal" or "bottom up" view of teaching. 
role of teachers in classrooms guide to the end that reflection is an essential and important part of teaching. The purpose of reflective teaching is to expand teachers' and student teachers' understanding of the teaching-learning process and their supply of strategic choices as language teachers (Murphy, 2001).

There are many activities related to reflective teaching which the teacher can use to investigate classroom teaching. The teachers can use different tools to access different sorts of information. Murphy (2001) divided these tools into some activities such as: five minute papers, teacher assessment surveys, questionnaires, dialogue journal, written assessments, peer collaborations, classroom observation, teacher logs, audio recording, video recording, and action research. Miyata (2002) used both web-based electronic teaching portfolio and video as devices for reflective inquiry and self-assessment by pre-service teachers. El-Dib (2003) mentioned some other tools of reflective teaching such as action research, reflection teams, role-playing, and debates. Moreover, Williams, Davis, Metcalf, and Covington (2003) referred to portfolio which can increase the students' reflection. The use of portfolio not only influences the pedagogical skills of pre-service teachers in their study, but the pedagogical and reflective skills of the instructors in the program as well.

Opp-Beckman and Klinghammer (2006) argued that good teachers are always learning from their own trial and error, from their students, from their peers and colleagues, and from their supervisors. Depending on the above mentioned views, the researcher had chosen three reflective lenses: student teacher's lens (journal writing), peers' lens institutional change, improved status for the teaching profession, improved students' learning and even restructuring of society. Bartlett (1990) suggested that the "improvement of teaching may be achieved through reflection" (p. 204). Richards (1990a) and Lange (1990) found that reflection is a key component of teacher development. Richards (1990a) added that self-inquiry and critical thinking can "help teachers move from a level where they may be guided largely by impulse, intuition, or routine, to a level where their actions are guided by reflection and critical thinking" (p. 5).

In addition, Posner (2005) confirmed that the reflection has also enhanced the teachers to investigate profoundly what they know about their students' values, assumptions and beliefs. Reflection has come to be widely recognized as a crucial element that may improve changes of teachers' attitudes in their professional growth (Calderhead\& Gates, 1993, Richards, 1991). Thus, the practice of reflective teaching helps us as professional teachers to examine our works (Bailey, 1997).

A central reason to be interested in reflective teaching is "to obtain conception and recognition of our teaching beliefs and practices and to learn to see teaching differently" (Gebhard\&Oprandy, 1999, p. 4). Supporting this view, Calderhead (1988) and Shin (2003) assured that the need for reflective teacher education has been argued on the grounds that it facilitates the linking of theory and practice, subjects the expertise of teachers to critical evaluation, and enables them to take a more active role in their own professional accountability. Ross, Bondy and Kyle (1993) described different assumptions about teaching and the 
related to the methodological concerns of teaching towards (what / why) questions that extend the reflective process to include issues" (p. 206). Farrell (1998) identified some components of a teacher development model which would give teachers the opportunities to reflect through different activities and provide external input for enriched reflection.

$\begin{array}{rrr}\text { Many } & \text { studies } & \text { consider } \\ \text { reflective } & \text { practice } & \text { during }\end{array}$ practicum as a means for prospective teacher development. El-Dib (1993) presented in her study a strong evidence that a dominating relationship rather than an empowering relationship characterized the supervisory meetings with prospective teachers. This study focused on the interaction between one supervisor and two student teachers over the duration of a teaching practice experience. The study took place in the Faculty of Education, Zagazig University. Two-third year Egyptian students in the English Department volunteered for the study. The teaching practice took place in a junior high school in KafrShukr. The instruments of the study were the taping and transcribing of the supervisor's meetings with the student teachers in the school and the prospective teachers' journals about their experience. Prospective teachers were asked to write their own thoughts concerns, problems and feelings about the experience. The results of the analysis showed an emerging concept of teaching as performance of predetermined steps rather than as a scientific activity or a reflective activity.

McCollum (1997) provided insights into the process of guiding reflection during an early field experience of pre-service teachers. The participants were pre-service teachers of a large university in the (peer observation), and student's lens (five-minute paper).

Some types of reflection are identified by many researchers. Richards (1991) mentioned that reflection has taken place during three parts process which involves the event itself, recollection of the event and review and response to the event. Frank (1999) added that to start to become a reflective teacher, write a mission statement and then develop a plan of action, maintain and monitor the plan, evaluate the plan, and take action. Farrell (1998) reported five types of reflection. The first type, technical rationality which examines one's use of skills and immediate behaviors in teaching with an established research/theory base. The second type, reflectionin-action, deals with on-the-spot professional problems as they occur. Thinking can be recalled and then shared later. The third, reflection-on-action, recalls one's teaching after the class. Teacher gives reasons for his/her actions/behaviors in class. The fourth, reflection-for-action, would proactive thinking in order to guide future action. Finally, action research which shows selfreflective enquiry by participants in social settings to improve practice.

The reflective teaching model was founded on Dewey's equation : Experience + Reflection $=$ Growth (as cited in McIntyre \& O'Hair, 1996). Wallace (1991) also offered a visual model of reflective teaching. A key component of this model is the reflective cycle, a term which Wallace explained it as being "a shorthand way of referring to the continuing process of reflection on received knowledge and experiential knowledge in the context of professional action (practice)" (p. 56). Another model was suggested by Bartlett (1990) in which "teacher should move from the (how to) questions that directly 
writing under various conditions. The participants of the study were 35 students of a one-year Graduate Diploma of Education. They were asked to keep a weekly journal. It was found that the provision of brief written feedback may be a sufficient stimulus to deepen the reflective process. The study had confirmed that students come to the journal writing task with a wide range of reflective skills and attitudes.

Cross-Cultural E-Mail was implemented by Liaw (2001) to provide EFL student-teachers in Taiwan with the opportunity to interact with bilingual / ESL preservice teachers in U.S. The participants of this study were 19 Taiwanese undergraduate students majoring in Foreign Language and Literature. And there were 7 U.S. pre-service teachers from the University of Houston-Downtown (UHD) who were seeking Spanish/English bilingual education certification. The two groups started the e-mail correspondence in the spring semester when practice teaching took place. The correspondence was done according to the participants' schedules. They were free to choose topics for discussion. The data collected included : 1) the e-mail entries and 2) the end of semester reflective reports. This reflective tool gave them the chance to reflect on various levels of their cultural social assumptions as well as attitudes toward language learning and teaching. Written reports showed that the student-teachers were clearly aware of such gains and changes and further manifested awareness of their changes and efforts to become language professionals.

In their study, Galanouli and Collins (2002) investigated the views of a group of Northern Ireland student teachers on
Southeastern part of the United States who enrolled in the teaching practicum for the fall semester, 1996 and volunteered to participate in the study. This study included some tools of reflective teaching such as reflective journal, video analysis, and peer observation. The pre-service teachers' (PTs) views on the value of guided reflection indicated that they perceived it as meaningful for their professional growth and development as prospective physical education teachers. It appeared that using the levels in the reflective framework helped these PTs intentionally act on their thoughts about teaching and gain ownership of their professional development.

Jokinen and Saranen (1998) examined the skills of the student teachers to assess their training lessons and their own working during the lesson and to enhance the student teachers' selfassessment. The participants of the study were teacher trainers, 13 in number, in faculities of education in the Finnish Universities and nearly 1000 student teachers practice at the Teacher Training School of Jyvaskyla every year and about 100 of them are student teachers of science. They collected the materials of their teacher training year by using portfolios. Findings of the experimentation showed that it seems to be difficult to understand self-evaluation as a natural part of the teaching and learning process. The student teachers did not focus their assessments on their own performance and on the basis of their performance. Rather, they chose to criticize students and external objects. Results also indicated that self-assessment of lessons needs to be integrated into the training process.

Bain et al. (1999) attempted to gain a greater understanding of the process and outcomes of Journal 
and the teachers towards using this model. The suggested model was experimented on a sample of 15 Saudi student teachers (science section) at the faculty of education. Instruments of the study included the Reflexive Teaching Scale and the Reflective Teaching Assessment Rubrics side by side with supervision including mentoring and observation to check the reflexive teaching cycle. The study included some tools of reflective teaching such as journal writing and peer observation. Findings showed that there were significant differences in the performance of the two groups in favor of the experimental group in all seven cases of the suggested model and in the total score. It was also found that there was a positive attitude towards using the reflective teaching approach. (Translated)

In a recent study, El-Dib (2003) tried to investigate prospective teachers' level of reflective thinking and if there are differences between third and fourth years student-teachers in their levels of reflective thinking. The sample was 230 students in the third year and 250 students in the fourth year. Out of the 230 third year students 160 submitted action research reports. Out of the 250 fourth year students 159 students submitted their studies. Fifty students of each group were randomly selected. The student teachers were introduced to action research and its principles during their EFL methodology course. They were required to conduct an action research study during the practicum. All students were required to submit written reports of their research after they finished their practicum. The research used the inventory of reflective thinking via action research. The results indicated that there was no significant difference between the two groups, except in how they computer conferencing as a system for establishing contact in order to exchange views on issues related to their courses and teaching practice, as well as information about themselves and their experiences. Three groups were randomly selected and combined normal seminar format with a computer conferencing link-up with student teachers at a university in the Republic of Ireland. Each student in Northern Ireland was assigned to a counterpart in the Republic of Ireland, to work in pairs. The Northern Ireland Network for Education hosted the computer conferencing using the Web Crossing system. A small-scale survey strategy was employed. Data about the use of computer conferencing were collected from questionnaires distributed to 29 participants in the survey from Northern Ireland; small-group semi-structured interviews $(n=7)$; and analysis of conference transcripts. Evidence from the data collected showed that participating in computer conferencing has indeed improved the information and communication technologies skills of the participants and has promoted their initial teacher awareness. At the same time, those involved in the study developed a reflective approach to their teaching practice through exchange of experiences on a variety of issues connected with the classroom. In addition, their attitude to IT appears to have become more positive, with increased self-confidence in their ability to use information and communication technologies.

A research study was conducted by Baksh (2003) to develop and improve the practical training program at Um-AlQura University through applying a suggested model of reflective teaching. The study investigated the views and attitudes of the student teachers, the supervisors 
indicated that the use of learning logs was a way to get to know the students and their writing needs.

Prospective teachers' reflective thinking levels were developed by AbouHadid (2004). Two groups of prospective teachers were assigned to represent the experimental and the control groups. A Profile of Reflective Thinking Attributes was used to determine prospective teachers' levels of reflective thinking both before and after the treatment for both groups. Objectives of each level of reflective thinking were determined and prospective teachers passed through many activities based on the process approach for developing each level of reflective thinking. Results indicated that the experimental group (prospective teachers) levels of reflective thinking were developed as the quantitative and the qualitative interpretations of the results of the study indicated.

A successful experience of using technology in developing reflective teaching for student teachers was made by Redmon (2004). E-Mail Discussions Groups was utilized as a tool of reflection. The participants were 6 middle school English teachers from two different campuses in an urban school district in North Texas. A description of the nature of the interaction between the members of the reflection group was provided. The ways in which the discussion evolved over the course of the study were analyzed too. Raw data consisted of verbatim transcripts of the discussions. Findings indicated that e-mail discussion groups appear able to encourage reflective thinking and reflective practice. It was found that e-mail reflection groups have the ability to reduce teachers' "reflective conservation", resulting in truly reflexive teachers who approach teaching and the teaching thought of their statement of problem in favor of third year student teachers.

An experiment was carried out by Rashed and Mahmoud (2003) to determine the effect of using Electronic Portfolios on evaluating the student teachers' performance and to know their attitudes towards using them. The sample of the study were 20 fourth year student teachers (science section) at the faculty of education, in Sultanate of Oman. The period of the study was 15 weeks. A pre-post test was used in this study. Findings showed that there were significant differences at the level 0.01 between the scores of (student teachers, supervisor of the faculty, teacher of the school, manager of the school, and the students) in favor of the post test. It was noticed that there was a positive attitude towards using Electronic Portfolios in the practicum program. (Translated)

In another study, Thomas (2003) reported an insightful statement on teaching and learning made in 1967 by Corder : "We will never be able to improve our ability to help our students until we learn". One effective way to do this is through reflective dialogue journals. The participants were 16 students. A weekly journal was assigned and the students were required to make weekly entries. There were no topics; rather the researcher instructed them to address their concerns about their writing, the class reading, the curriculum, the class lectures and anything else related to academic writing. The journal was informed and carried out for a full semester. As a result, the students learned that they could make positive changes in their learning by using the logs to focus and reflect on their personal writing process and work out problems and stumbling blocks on their own. Findings 
courses were conducted in Spring 2004 and Spring 2005 at a research-intensive university located in Midwestern United States. The online course consisted of forums for students to access discussions, post assignments, and respond to inquiries. The findings reflected evidence of group development sequence of forming, storming, norming, performing, and adjourning within both courses. This study determined that critical reflection was especially important when facilitating adults in the online environment. When students are allowed to provide those reflections, they provide evidence of group development and a feeling of ownership in the class.

\section{Commentary:}

In the light of the previous literature review, it is clear that the focus is on using reflective teaching for preparing both teachers and student teachers. They also focused on the positive effects of critical reflection and its activities on teaching. GlowackiDudka and Barnett (2007) applied critical reflection within the online environment in order to assess group development. They pointed out that when students are allowed to provide those reflections, they provide evidence of group development and a feeling of ownership in the class. The preservice teachers' views on the value of guided reflection indicated that they perceived it as meaningful for their professional growth and development as prospective physical education teachers (McCollum, 1997). Written reports showed that the student-teachers were clearly aware of such gains and changes and further manifested awareness of their changes and efforts to become language professionals (Liaw, 2001).

Reflective practice, as dealt with earlier, is discussed by various profession in a more thoughtful and collegial way.

One case study about the effects of using reflective teaching to develop teaching skills of EFL student teachers was presented by El-Sayed (2005). Some tools of reflective teaching were applied on nine student teachers during the practicum period. These tools are reflective journals, action research, group discussion, action planning, and observation. Each case of those student teachers was analyzed for expected problems, authentic ones and prominent teaching practices, using reflective teaching journals. These journals were ordered before being analyzed. Likewise, the problems were mentioned under each case according to the time they appeared in the course of teaching. Then, the "questionnaire" and the "reflection time sheets" were analyzed for each one's level of satisfaction and insightful remarks. Journals were written and filled in by the student teachers. Observation sheets were analyzed to shed more light on each case and the class practices. As a result, student teachers recognized their teaching problems and developed solutions, satisfying their students' needs. In addition, most of the student teachers were satisfied with their experience in their first encounter with the teaching profession. Moreover, they claimed their need to be model reflective practitioners in the future.

Glowacki-Dudka and Barnett (2007) applied critical reflection within the online environment in order to assess group development. One specific reflective tool, Critical Incident Questionnaire (CIQ), is used to assess group development. A qualitative multicase study was used for this research. The study context was a sample of two sixteen week online, asynchronous graduate courses on adult teaching strategies. The 
\& El-Sayed, 2005). These activities were used to investigate classroom teaching and access different sorts of information and to gain awareness of teaching. More importantly, findings of some studies were of benefit to the present study in designing and developing the research instruments (Murphy, 1992; Brown, 1994; Baksh, 2003; \& ElSayed, 2005).

\section{Statement of the Problem}

Through the teaching practice, student teachers acquire some facts about the characteristics of a qualified teacher and teaching. They learn more about the beneficial methods of teaching, how to choose and use instructional materials, how to manage the class and how to evaluate their students. Teaching practice program aims at making qualified EFL teachers.

An interview questions conducted with some supervisors and a group of English teachers ( $\mathrm{n}$ = 25) (Appendix A). Based on content analysis of responses ( 100 $\%$ ) of the respondents reported that the majority of the student teachers' classroom performance is ineffective. As a result, the aim of teaching practice is not achieved.

Also, according to the computery search, no experimental studies have been conducted on the use of reflective teaching practice in EFL teacher education programs in Saudi Arabia.

\section{Purposes of the Study}

The main purpose of the present study is to develop student teacher's classroom performance by using reflective teaching. From this main purpose, the following sub-purposes emerge:

1- To investigate the effects of the reflective teaching approach on the classroom performance of English major student teachers. researchers as to play a basic role in the improvement of teachers' classroom performance and how it must be a dominant theme in teacher education. Zeichner and Liston (1996) reported that a reflective teacher takes responsibility for his or her own professional development. Much of the research work, like the present study, attempted to develop and the evaluate actual classroom performance and competencies of teachers and student teachers by using reflective practice (Bowes, 1997; Jokinen\&Saranen, 1998; \& Al-Mutawa, 2004). Others aimed at developing student teachers' teaching skills (e. g., El-Saey, 2005). Others tried to enhance student teachers' self-assessment such as (Jokinen\&Saranen, 1998).

Schon (1987) described his own reflective practice as "a dialogue of thinking and doing through which I become more skilled" (p. 31). To be an effective teacher, it is not enough to be able to recognize what happens in the classroom. Rather, it is imperative to understand the "why" "how" and "what if" as well. This understanding comes through the consistent practice of reflective thinking. A number of previous studies focused on improving reflective thinking levels of prospective teachers such as AbouHadid (2004), or determining the level of prospective teachers' reflective thinking like El-Dib (2003). Redmon (2004) indicated that e-mail discussion groups appear able to encourage reflective thinking and reflective practice.

Like the present study, a number of studies adopted different reflective teaching activities like journal writing, portfolios, peer observation, action research and writing conferences (McCollum, 1997; Bain et al., 1999; Jokinen\&Saranen, 1998; Baksh, 2003; El-Dib, 2003; Thomas, 2003; 
visual aids, in favor of the experimental group.

3- There are statistically significant differences at 0.01 level between the experimental group's means of scores in the pre and post-test of classroom performance on the analytic scoring rubric, in favor of the post test.

4- There are statistically significant differences at 0.01 level between the experimental group's means of scores in the pre and post-test of classroom performance on each of the six areas of analytic scoring rubric criteria i. e., giving effective instructions, using motivated question techniques, choosing suitable techniques for correcting mistakes, praising the correct answers, systematic handling of the blackboard, and making and using available audio-visual aids, in favor of the post test.

5- There are favorable attitudes among the experimental group toward reflective teaching practices.

\section{Significance of the Study}

1- It deals with one of the major issues necessary for teacher development, i.e., promoting reflective practice that is greatly recommended by many theorists in the field of teacher education.

2- The study presents a validated instrument (performance criteria) and scoring rubrics that may be helpful in observing and evaluating English teachers, mainly for pre-service training purposes.

3- It offers a reflective teaching approach based on training workshop which may help prospective English teachers become critically reflective teachers.

\section{Delimitations of the Study}

The study is delimited to:
2- To determine the experimental group's attitudes toward using reflection activities to improve their classroom teaching practices.

\section{Questions of the Study}

Based on the above mentioned problem, the present study tries to answer the following questions:

1- What are the areas of classroom teaching practices in which the student teachers need the greatest help?

2- How effective is the use of reflective teaching approach in developing classroom performance of English major student teachers?

3- What is the effect of reflective teaching approach on the six stated areas of classroom performance of the student teachers?

4- What are the experimental group's attitudes towards reflective teaching practices?

\section{Hypotheses of the Study}

The present study attempts to verify the following hypotheses :

1- There are statistically significant differences at 0.01 level between the mean scores of the control and experimental groups in the post test of classroom performance on the analytic scoring rubric, in favor of the experimental group.

2- There are statistically significant differences at 0.01 level between the mean scores of the control and experimental groups in the post test of classroom performance on each of the six areas of analytic scoring rubric criteria i. e., giving effective instructions, using motivated question techniques, choosing suitable techniques for correcting mistakes, praising the correct answers, systematic handling of the blackboard, and making and using available audio- 
learner response, and then to try to improve it" (p. 226).

Tice (2006) viewed reflective teaching as "looking at what you do in the classroom, thinking about why you do it, and thinking about if it work- a process of selfobservation and self evaluation" ( $\mathrm{p}$. 236).

Based on the above definitions, reflective teaching is operationally defined as an approach in which the student teachers reflect (thinking back on what they have done in class) critically on their teaching experiences, as a way of improving classroom practices through using journals, peers, and learner response.

\section{Sample of the Study}

A group of fourth year $(n=32)$ EFL students enrolled at Girls' College of Education in Jazan were randomly selected (simple random sample) from a total population of students $(\mathrm{N}=127)$. They were involved in the teaching practice at the school secondary level. They randomly divided into two groups (control and experimental). They have the same previous teaching practice experience (one term at the intermediate level).

\section{Design of the Study}

The pretest - posttest equivalent groups design was adopted. Accordingly, experimental and control groups were equated by random assignment (Best \& Khan, 1986). The experimental group was trained in using the reflective approach during their teaching practice while the control group had the traditional supervisory practices. The effect of treatment was judged by the difference between the post observation scores of the experimental and control groups. The descriptive design was also used to determine the attitudes of the experimental
1- Fourth year English major students enrolled at Girls' College of Education in Jazan.

2- Provide a range of activities for prospective teachers of English to reflect on their work during practicum period (8 weeks) which started in the first semester of the academic year.

3- One type of reflection which is "reflection on action" which focuses on thinking subsequent to the completion of the event. (Thinking back on what we have done in class).

4- Using only three different tools of reflective teaching namely, journal writing, peer observation, and five-minute papers.

5- Certain areas of classroom teaching practices i. e., giving effective instructions, using motivated question techniques, choosing suitable techniques for correcting mistakes, praising the correct answers, systematic handling of the blackboard, and making and using available audio-visual aids.

\section{Definition of Terms}

Reflective teaching approach. Pennington (1992) defined reflective teaching as "deliberating on experience and that of mirroring experience" (p. 47). In other words, Zeichner and Liston (1996) wrote that "Dewey defines reflective action as that which involves active, persistent, and careful consideration of any belief or practice in light of reasons that support it and the further consequences to which it leads" (p. 9).

Another definition was provided by Opp-Beckman and Klinghammer (2006) as "systematically and actively think about what happens in the classroom, both in terms of the teaching itself and in terms of the 
relevance of each item. Their feedback led to replace some items with others such as "making and using available audio-visual aids" instead of "used materials" and "praising the correct answers" instead of "giving feedback". Other items were deleted such as "praise behaviors", "organizing books and materials", and "revising the previous lesson". Based on the jury comments, necessary changes and modifications were made.For final form of the checklist, see Appendix A.

Intrinsic validity of the checklist was calculated using the following formula (Al-Saeed, 1978, p. 402) (Translated):

Intrinsic Validity = $\sqrt{\text { Reliability Item }}$

Intrinsic Validity of the CCTP = $\sqrt{.826}=0.908$

- Reliability of the CCTP

To establish the reliability of the CCTP, the test-retest method was used. The checklist was administered to a group of student teachers $(n=20)$. After two weeks it was administered to the same group. The correlation coefficient between the test and retest scores was computed using Pearson Correlation Formula. Results are presented in table (1).

Table (1) The Correlation Coefficient Between the Test \& Re-test Scores of the (CCTP)

\begin{tabular}{cccc} 
(CCTP) & & & \\
\hline Administration & M & SD & ' ' \\
First & 26.45 & 3.966 & \\
Second & 26.00 & 3.933 & $.826^{*}$
\end{tabular}
tailed).

* Correlation is significant at 0.01 level (2-

As shown in table (1), while the mean score of the first administration is (26.45) with a standard deviation of (3.96), the mean score of the second group's towards using reflection activities.

\section{Variables of the Study}

The variables of the study are:

- Reflective teaching approach as an independent variable.

- Classroom performance of EFL student teachers as a dependent variable.

\section{Instruments of the Study}

To carry out the experiment, the following instruments were constructed :

1- Checklist of classroom teaching practices (CCTP).

- Description of the CCTP

The purpose of this checklist is to determine the areas of classroom teaching practices (day to day practices of teachers inside the classroom) for which EFL student teachers need the greatest help. It includes 20 items that represent different classroom teaching practices. The instrument is based on a three-point scale ranging from most important (2), to less important (1), and to not important (0). Clear instructions are provided for the participants. They are asked to decide which areas of classroom teaching practices they think to be important and needed by EFL student teachers. They have to put a tick $(\sqrt{ })$ in the box corresponding to one of the three choices. An item sample is given.

\section{- $\quad$ Piloting the CCTP}

- Validity of the CCTP

Based on the previous literature and the results of the interview questions with some EFL teachers and supervisors, a preliminary checklist (25 items) of classroom teaching practices was prepared. To ensure that the checklist items were clear and appropriate, it was submitted to a jury of experts for content and face validity. They were requested to read the items of the checklist and make their inputs and comments regarding the clarity and the 
student teachers. Name of observer, signature, and total score are placed at the end of the rubric.

\section{- $\quad$ Piloting the ASR}

- Validity of the ASR

This scoring rubric was submitted to a panel of jury for content and face validity. They were requested to give their opinions concerning the adequacy and appropriateness of performance levels and the clarity of each indicator, its relevance to the criterion, and its consistency with other indicators. They reported that the levels of performance are adequate, appropriate, and varied. Each of the given indicators is clear and relevant to the criterion and is consistent with other indicators. In addition, their feedback led to replace some statements with others such as "distributes questions on all students" instead of "calls on all students in the class" and "praises who ever answers correctly" instead of "praises good and correct answer". Also, some items were added or deleted. Based on the comments given by the jury, necessary changes and modifications were made. For final version, see Appendix C .

- Internal consistency of the ASR

To determine the internal consistency of the six criteria of the ASR, the correlation coefficient for each criterion of the analytic scoring rubric with the whole rubric was computed using Pearson Correlation Formula. Results are reported in table below.

Table (2) The Correlation Coefficient of the Six Criteria of the (ASR) with the Whole Rubric

\begin{tabular}{lccc}
\hline Criterion & $\mathrm{M}$ & $\mathrm{SD}$ & ${ }^{\prime} \mathrm{r}$ \\
\hline $\begin{array}{l}\text { Giving effective } \\
\text { instructions }\end{array}$ & 12.70 & 3.21 & .940 \\
$\begin{array}{l}\text { Using motivated } \\
\text { question techniques }\end{array}$ & 14.80 & 2.42 & .942 \\
$\begin{array}{l}\text { Choosing suitable } \\
\text { techniques for }\end{array}$ & 13.60 & 2.60 & .952 \\
$\begin{array}{l}\text { correcting mistakes } \\
\text { Praising the correct }\end{array}$ & & & $*$ \\
& 7.70 & 2.56 & .816
\end{tabular}

administration is (26.00) with a standard deviation of (3.93). The correlation coefficient is (.826) which is statistically significant at the 0.01 level. Based on these results, the CCTP is valid and reliable.

\section{2- Analytic scoring rubric (ASR).}

\section{- Description of the ASR}

It is a scoring scheme for grading classroom performance of the student teachers. It includes the criteria areas that are thought to be important by the student teachers according to the results of the CCTP. It is comprised of three components: criteria, indicators, and levels of performance. Each indicator is accompanied by four alternative levels of performance: Outstanding, Efficient, Developing, and Unsatisfactory. The six criteria are: giving effective instructions, using motivated questioning techniques, choosing suitable techniques for correcting mistakes, praising the correct answers, systematic handling of the blackboard, and making and using available audio-visual aids. A number of statements of expected performances (indicators) is derived from each criterion. The rubric is based on a four-point scale ranging as: outstanding (4), efficient (3), developing (2), and unsatisfactory (1). Student teachers can receive $1,2,3$, or 4 points for each indicator within a criterion. Total possible score is one-hundred. The instructions are given to the observer. These instructions include how this rubric may help observer to assign score points to the classroom performance of the student teachers. They contain a brief description of the rubric design. The observer is asked to assign score points to the classroom performance of the 
between the two raters is .936 . It is statistically significant at the level of 0.01 . Based on these results, the ASR is valid and reliable.

\section{3-Workshop:becoming} critically reflective EFL teacher.

- Description of the Workshop

- Goals

1- To promote reflective thinking.

2- To develop teachers' ability to assess and evaluate a range of teaching and learning experiences in their own professional practice.

3- To raise awareness of ethics and values within the teaching profession when working with learners and colleagues.

4- To recognize the importance of engaging in critical reflection upon professional practice.

5- To introduce the student teachers to a variety of reflective teaching activities.

\section{- Objectives}

By the end of the workshop, the trainees should:

- be aware of the role of reflection

- be able to use some tools to facilitate reflective thinking about their field experiences.

- be familiar with journal entries.

- be able to analyze a sample of journal entries.

- be able to format a journal entry.

- be able to use journaling strategy.

- provide a personal response to a critical incident involving observation and evaluation of teaching.

- be able to use peer observation strategy.

- be able to use five-minute papers strategy answers

Systematic handling of $\quad \begin{array}{lll}12.55 & 1.73 \quad & .765\end{array}$

the blackboard

Making and using

available audio-visual

aids

*Correlation is significant at 0.01 level (2-

tailed).

As shown in table (2), the correlation coefficient for each criterion i. e., giving effective instructions, using motivated question techniques, choosing suitable techniques for correcting mistakes, praising the correct answers, systematic handling of the blackboard, and making and using available audio-visual aids, with the whole rubric were $.940, .942$, $.952, .816, .765, .835$ respectively. These results are statistically significant at the 0.01 level and indicate that ASR has high internal consistency.

- Reliability of the ASR

Scorer reliability was used to establish the ASR reliability. A sample of student teachers $(n=20$ ) were visited and evaluated by two raters (researcher and an external evaluator) independently. A grade was given to the student teacher on each visit using the scoring rubric. The correlation coefficient between the two scores was computed using Pearson Correlation Formula. Results are presented in table (3).

Table (3) The Correlation Coefficient Between the Scores of the Two Raters of (ASR)

\begin{tabular}{ccccc}
\hline RSR) & & & & \\
& Rater & SD & ' ${ }^{\prime}$ \\
& & & \\
\hline One & 70.4 & 12.40 & \\
& 0 & 7 & .93 \\
Two & 70.8 & 11.60 & \\
& 5 & 4 &
\end{tabular}

\footnotetext{
* Correlation is significant at 0.01 level (2tailed).
}

As shown in table (3) above, while the mean score of the first rater is (70.40) with a standard deviation of (12.40), the mean score of the second rater is (70.85) with a standard deviation of (11.60). The correlation coefficient 
correct answers, systematic handling of the blackboard, and making and using available audiovisual aids, and remarks). On the right side, the student teacher would comment on her colleague's performance For classroom observation format, see Appendix D. The trainees are asked to observe their colleagues in class and write a narrative description and comments on certain aspects using this format.

- Session 3: Activity (Five-Minute Papers)

The guidelines for using fiveminute papers are discussed with the trainees. Then, the five-minute papers format is explained.It is designed to find out how learners are perceiving and responding to the student teacher' efforts. It consists of 14 questions which are administered to the students in their own language (Arabic). Students are asked to express their opinions freely therefore their names are not required to be written. For five-minute papers format, see Appendix D.

\section{- Training Techniques}

Lectures, Discussions, Debates, Individual work, Group work, Demonstration.

\section{- Instructional Materials}

Cartoon, Handouts, and Transparencies

\section{- Work Committee}

- The researcher ( director of the session )

- Trainees : a group of fourth year students majoring in English at Girls College of Education, Jazan (16 students).

\section{- Location}

"Secondary School the First for girls", Sabya, Jazan.

\section{- Duration}

Two consecutive days ( three hours for the first day and six hours for the next one).

\section{- Evaluation Procedures}

\section{- Content}

The workshop consists of an introductory session and three other sessions as follows:

- Introductory session:

It presents a lecture and a debate on some outlines i. e., reflective teaching and its importance, the way reflection takes place, and the tools of reflective teaching. At the end of the session, the trainees are asked to write down answers of some prepared questions around the lecture.

- Session 1: Activity (Journal Writing)

The benefits of journaling is expressed to the trainees. A sample of journal entries is analyzed through individual/ group work. Dialogue journal format is explained. This format is intended to follow up and assess the subjects' progress in reflective teaching through the training. It consists of four cores which are heading (name, date of entry, and time of entry), brief sequencing of events, elaboration on details of one or two episodes based on level of excitement, puzzlement, or confirmation, and analysis of the episode (possible explanation for event, plan of action, acting, and reviewing). For dialogue journal writing, see Appendix, D. The criteria for evaluating journal writing and some guidelines for keeping a journal are also discussed. Debriefing is held at the end of this session.

- Session 2: Activity (Peer Observation)

The guidelines for peer observation are presented. Then, the classroom observation format is discussed.This format is developed to help student teachers reflect on their classroom teaching practices with peers. It consists of seven major sections which are: giving effective instructions, using motivated question techniques, choosing suitable techniques for correcting mistakes, praising the 
workshop were sufficient. Group work was the most thing the student teachers liked about the workshop However, based on their suggestions and comments, necessary changes were made. For final version of the workshop, see Appendix D.

\section{4- Questionnaire on attitudes towards reflective teaching practices (QARTP) \\ - Description of the QARTP}

This feedback questionnaire is intended to determine the experimental group's attitudes towards using reflective teaching activities. The QARTP consists of 32 statements that represent four sections: reflective teaching, journal writing, peer observation, and five-minute papers. Statements are of both negative and positive nature. The first and second sections has ten positive statements and two negative statements. The third and fourth sections has five positive statements and one negative statement. This instrument is based on a five-point scale (Likert type) ranging as strongly agree (5), agree (4), undecided (3), disagree (2), and strongly disagree (1). Clear and simple directions regarding subjects' responses to the questionnaire are provided. They are asked to read each statement carefully and indicate their responses to each statement by putting a tick $(\sqrt{ })$ in the box responding to only one of the five choices. An item sample is provided.

Scores for positive and negative statements are given as follows: 2-1)

Positive Statements $=(5-4-3-$ 4-5)

Negative Statements $=(1-2-3-$

The following score values would be revealing:

$32 \times 5=160$ Most favorable attitude
One way to measure the success of the workshop is to determine if the student teachers had indeed made gains during the practicum period. The evaluation of the workshop itself is provided. A feedback session (debriefing) is held after each activity.

- $\quad$ Piloting the Workshop

- Validity of the Workshop

This workshop was given to a jury of experts to establish the face validity and suitability of the workshop materials for the student teachers. They were requested to provide their inputs and opinions regarding the following aspects: goals, objectives, contents, training techniques, instructional/ supportive materials, duration, and evaluation system. The jury members' comments revealed that the objectives are clearly stated, appropriate, and can be measured. The training techniques and instructional/supportive materials are varied and purposeful. Workshop committee is appropriate for its purpose. The guidelines are clearly presented and will hardly pose any difficulty for the student teachers. The procedure is comprehensive, consistent, and well sequenced. In addition, the jury feedback led to add or replace some materials such as replace the item "duration" instead of "time". According to the jury members' comments, necessary changes and modifications were made.

The workshop was field tested on a sample of student teachers (n $=10$ ) as a pilot study (since of the study's nature). An evaluation form was given to the student teachers at the end of the workshop. This form was designed to find out to what extent the student teachers had perceived the workshop to be successful and the feasibility of applying such a reflective workshop. Results indicated that the instructions were clearly presented and the materials of the 
administration of the same instrument. The coefficient of correlation between the test and retest scores was computed using Pearson Correlation Formula. Results are shown in table (4).

Table (4) The Correlation Coefficient Between the Test \& Re-test Scores of the (QARTP)

\begin{tabular}{cccc}
\hline Administration & M & SD & ' r' \\
\hline First & 126.00 & 4.082 & \\
Second & 124.60 & 4.623 & $.801 *$
\end{tabular}

* Correlation is significant at 0.01 level (2 tailed).

As shown in table (4), while the mean score of the first administration is (126.00) with a standard deviation of (4.08), the mean score of the second administration is (124.00) with a standard deviation of (4.62). The correlation coefficient is (.801) which is statistically significant at the 0.01 level. Results indicated that the QARTP is valid and reliable.

\section{Procedures of the Study}

Prior to the experiment, an interview questions was carried out with a group of supervisors and English teachers as a pilot study. Depending on the interview results and the previous literature, a preliminary checklist of classroom teaching practices was designed. Later, its validity and reliability was determined. The developed checklist (CCTP) was administered to the subjects to identify the criteria areas of classroom teaching practices for which they felt the greatest need to help. The experiment lasted for 8 weeks. Both control and experimental groups were pre-observed to measure their classroom teaching performance. The pre-observation took place at the beginning of the practicum period.

The experimental group were trained to reflect. They were
$32 \times 3=96$ Neutral attitude $32 \times 1=32$ Most unfavorable attitude

The score for any individual would fall between 32 and 160 . Above 96 if opinions tended to be favorable to the given point of view and below 96 if opinions tended to be unfavorable (Best and Khan, 1986).

- $\quad$ Piloting the QARTP

- Validity of the QARTP

It was submitted to a panel of jury experts for face and content validity. They were requested to provide their inputs and comments concerning the clarity and the relevancy of each statement. Their suggestions revealed ambiguities and unrelated statements (items) that do not contribute to the questionnaire purpose. The preliminary version of the questionnaire consisted of 38 statements. Based on the jury feedback, some items were modified, others were added and others or deleted, e. g., "PO makes me feel difficult as being observed" instead of "PO is not useful for improving my teaching skills". Accordingly, necessary changes and modifications were made. For final version, see Appendix B.

Intrinsic validity of the QARTP was obtained by applying the following formula:

Intrinsic Validity $=$
$\sqrt{\text { Re liability Item }}$
Intrinsic Validity of the
QARTP $=\sqrt{.801}=0.89$

- $\quad$ Reliability of the QARTP

To determine the reliability of the QARTP, the test-retest method was used. It was administered to the experimental group who attended the workshop $(\mathrm{n}=10)$. After two weeks it was administered to the same group. The subjects' responses on the questionnaire were correlated with responses on the second 
Independent samples t-test (2tailed) was used to determine if there were any significant differences in the mean scores between the experimental and control groups on the pre and posttest. Also, paired samples t-test (2tailed) was used to determine if there were any significant differences between the mean scores of the same group (experimental) on the pre and post test. For statistical analysis, the alpha level of significance of 0.01 of confidence was adopted. To measure the effect size " $d$ " of using the reflective teaching approach (independent variable) on the classroom performance (dependent variable) of the experimental group, Eta Squared " $\eta^{2}$ " was computed using " $\mathrm{t}$ " value for the differences between the means.

\section{Results Concerning the Hypotheses and Questions of the Study}

This part presents a discussion of the questions and hypotheses of the study in light of the data analysis and interpretation of the results.

\section{1- Results of the checklist of classroom teaching practices (CCTP).}

Table (5) shows the frequency and percentage of each item of the checklist. The rank of each item is also presented to indicate the most important classroom teaching practices needed by the control and experimental groups.

Table (5) Frequency, Percentage and Rank of Classroom Teaching Practices Needed by the Subjects

\begin{tabular}{lccc}
\hline \multicolumn{1}{c}{ Item } & $\mathrm{f}$ & $\%$ & $\begin{array}{c}\text { Ran } \\
\mathrm{k}\end{array}$ \\
\hline $\begin{array}{l}\text { Giving effective } \\
\text { instructions }\end{array}$ & 26 & 81.2 & 1 \\
$\begin{array}{l}\text { Using motivated question } \\
\text { techniques }\end{array}$ & 24 & 75.0 & 2 \\
$\begin{array}{l}\text { Choosing suitable } \\
\text { techniques for correcting } \\
\text { mistakes }\end{array}$ & 22 & 68.7 & 3 \\
\end{tabular}

introduced to different activities of reflection in a workshop which was conducted in the first week of the practicum period at Secondary School the First for girls, SabyaJazan.

The period during practicum was devoted wholly to reflection practices. Each participant made a dialogue journal format after each class. Also, each student teacher visited her partner class and completed the classroom observation format using the procedures that both parties had agreed on. Once every two weeks, the student teacher administered five-minute papers to find out learners' feedback.

Before the end of practicum, the two groups (control and experimental) were also postobserved. The performance of both groups was rated (pre and post observation) according to six criteria. Each subject was evaluated on two visits by the researcher and an external evaluator independently. A grade was given to the subject on each visit using the analytic scoring rubric (ASR). The average of the two scores assigned by the two raters became the final score.

Upon the completion of the practicum period, a feedback questionnaire on attitudes towards reflective teaching practices was administered to the experimental group to determine their attitudes towards using the reflective teaching approach.

\section{Data Analysis}

Data collected were statistically analyzed qualitatively and quantitatively using a set of statistical procedures through the computer package SPSS Windows (version 10.0). Descriptive statistics such as means, standard deviations, frequencies, ranks and percentages were computed. 
class, and using students' first language through lesson procedures, respectively. In addition, using suitable timing of class, explaining / discussing the grammatical rules, and using EFL patterns and structures in different situations had similar frequency and percentage. In other words, giving instructions had the highest percentage $(81.25 \%)$ whereas use of Arabic had the lowest percentage $(15.62 \%)$. Thus, these findings will answer of the first question "What are the areas of classroom teaching practices in which the student teachers need the greatest help?".

2- Results of the pre test for both groups (experimental and control).

\section{a. Results of overall classroom performance}

The pre test scores were analyzed using independent samples t-test. The mean scores, standard deviations, t-value, and t significance of overall classroom performance of the two groups on the pre-test are presented in table (6) below.

Table (6) $t$-Value for Overall Classroom Performance of Both Groups (Pre-test)

\begin{tabular}{|c|c|c|c|c|c|}
\hline Variable & $\begin{array}{c}\text { Gro } \\
\text { up }\end{array}$ & $\bar{M}$ & SD & $\mathrm{t}$ & $\begin{array}{c}\text { Sig. } \\
(2- \\
\text { taile } \\
\text { d) }\end{array}$ \\
\hline $\begin{array}{c}\text { Overall } \\
\text { Classroo }\end{array}$ & Exp. & $\begin{array}{c}61.3 \\
1\end{array}$ & $\begin{array}{c}5.6 \\
7\end{array}$ & $\begin{array}{l}0.14 \\
6\end{array}$ & .885 \\
\hline $\begin{array}{c}\mathrm{m} \\
\text { Performa } \\
\text { nce }\end{array}$ & Con. & $\begin{array}{c}61.0 \\
3\end{array}$ & $\begin{array}{c}5.2 \\
2\end{array}$ & & \\
\hline
\end{tabular}

As shown in table (6), while the mean score of the experimental group was 61.31 with a standard deviation of 5.67, the mean score of the control group was 61.03 with a standard deviation of 5.22. The obtained t-value (0.146) revealed that no statistically significant differences at $p<.01$ level were found between the mean scores of the experimental and control groups in the pre-test of overall classroom performance. Figure (1) illustrates the result of table (6).

\begin{tabular}{|c|c|c|c|}
\hline $\begin{array}{l}\text { Praising the correct } \\
\text { answers }\end{array}$ & 21 & $\begin{array}{c}65.6 \\
2\end{array}$ & 4 \\
\hline $\begin{array}{l}\text { Systematic handling of the } \\
\text { blackboard }\end{array}$ & 20 & $\begin{array}{c}62.5 \\
0\end{array}$ & 5 \\
\hline $\begin{array}{l}\text { Making and using } \\
\text { available audio-visual aids }\end{array}$ & 19 & $\begin{array}{c}59.3 \\
7\end{array}$ & 6 \\
\hline $\begin{array}{l}\text { Using suitable timing of } \\
\text { class }\end{array}$ & 18 & $\begin{array}{c}56.2 \\
5\end{array}$ & 7 \\
\hline $\begin{array}{l}\text { Explaining / discussing } \\
\text { the grammatical rules }\end{array}$ & 18 & $\begin{array}{c}56.2 \\
5\end{array}$ & 8 \\
\hline $\begin{array}{l}\text { Using EFL patterns and } \\
\text { structures in different } \\
\text { situations }\end{array}$ & 18 & $\begin{array}{c}56.2 \\
5\end{array}$ & 9 \\
\hline $\begin{array}{l}\text { Posturing and moving } \\
\text { around the class }\end{array}$ & 17 & $\begin{array}{c}53.1 \\
2\end{array}$ & 10 \\
\hline $\begin{array}{l}\text { Demonstrating the } \\
\text { different English language } \\
\text { skills }\end{array}$ & 16 & $\begin{array}{c}50.0 \\
0\end{array}$ & 11 \\
\hline $\begin{array}{l}\text { Dealing with students' } \\
\text { individual differences }\end{array}$ & 14 & $\begin{array}{c}43.7 \\
5\end{array}$ & 12 \\
\hline $\begin{array}{l}\text { Using vibration of voice } \\
\text { level }\end{array}$ & 12 & $\begin{array}{c}37.5 \\
0\end{array}$ & 13 \\
\hline $\begin{array}{l}\text { Endeavoring to involve } \\
\text { the students in different } \\
\text { class activities }\end{array}$ & 11 & $\begin{array}{c}34.3 \\
7\end{array}$ & 14 \\
\hline $\begin{array}{l}\text { Calling / addressing } \\
\text { students in their names }\end{array}$ & 9 & $\begin{array}{c}28.1 \\
2\end{array}$ & 15 \\
\hline $\begin{array}{l}\text { Grouping students in pairs } \\
\text { / groups and controlling } \\
\text { them }\end{array}$ & 8 & $\begin{array}{c}25.0 \\
0\end{array}$ & 16 \\
\hline Item & $\mathrm{f}$ & $\%$ & $\begin{array}{c}\text { Ran } \\
k\end{array}$ \\
\hline $\begin{array}{l}\text { Exerting efforts to deal } \\
\text { with the students' } \\
\text { problems }\end{array}$ & 7 & 21.87 & 17 \\
\hline $\begin{array}{l}\text { Developing a good } \\
\text { rapport with the } \\
\text { students }\end{array}$ & 7 & 21.87 & 18 \\
\hline $\begin{array}{l}\text { Bringing various } \\
\text { resources to class }\end{array}$ & 6 & 18.75 & 19 \\
\hline $\begin{array}{l}\text { Using students' first } \\
\text { language through lesson } \\
\text { procedures }\end{array}$ & 5 & 15.62 & 20 \\
\hline
\end{tabular}

As shown in table (5) the items which got the highest frec the items which got the lowest frequency and percentage were calling / addressing students in their names, grouping students in pairs / groups and controlling them, exerting efforts to deal with the students' problems, developing a good rapport with the students, bringing various resources to 
mean scores of both the experimental and control groups in the pre-test of the six cores of classroom performance. The achieved mean scores of the experimental group were (10.00), (12.96), (11.87), (6.50), (11.56), (8.40) for giving effective instructions, using motivated question techniques, choosing suitable techniques for correcting mistakes, praising the correct answers, systematic handling of the blackboard, and making and using available audio-visual aids, respectively. On the other hand, the control group received (10.37), (13.15), (12.18), (5.87), (11.25), (8.18) for giving effective instructions, using motivated question techniques, choosing suitable techniques for correcting mistakes, praising the correct answers, systematic handling of the blackboard, and making and using available audio-visual aids, respectively. Figure (2) illustrates the results in table (7).

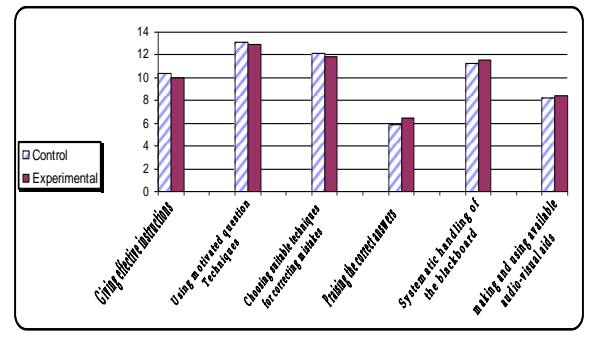

Figure (2) Comparison between scores of both groups on the six cores of classroom performance (pre-test)

These results support the data in table (7) which provides evidence that the two groups were homogeneous and almost identical, in the sense that, they got similar means and standard deviations on the pre-test of classroom performance, prior to the treatment. This means that differences between the mean scores of control and experimental groups in the post test could be achieved to the effect of using reflective teaching approach.

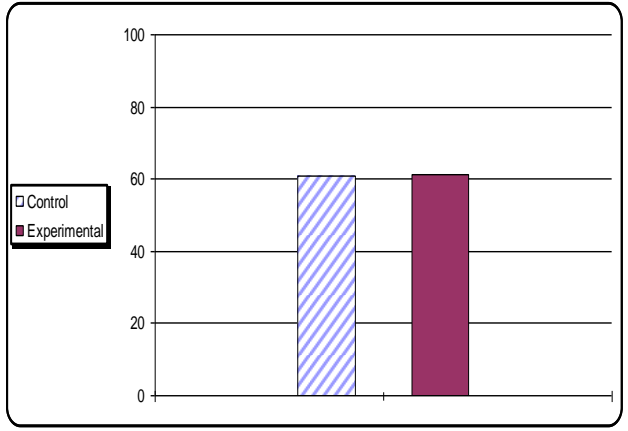

Figure (1) Comparison between scores of both groups in overall classroom performance (pre-test)

\section{b. Results of the six cores of classroom performance}

The pre test scores were analyzed using independent samples t-test. Table (7) offers the mean scores, standard deviations, $t-$ values, and $t$ significance of the six cores of classroom performance for the two groups on the pre-test.

Table (7) t-Values for the Six Cores of Classroom Performance of Both Groups (Pre Test)

\begin{tabular}{|c|c|c|c|c|c|}
\hline $\begin{array}{l}\text { Classroom } \\
\text { Teaching } \\
\text { Practic }\end{array}$ & $\begin{array}{c}\text { Gro } \\
\text { up }\end{array}$ & $\bar{M}$ & $\begin{array}{l}\mathrm{S} \\
\mathrm{D}\end{array}$ & $\mathrm{t}$ & $\begin{array}{l}\text { Sig. } \\
(2- \\
\text { tailed } \\
)\end{array}$ \\
\hline $\begin{array}{l}\text { Giving } \\
\text { effective } \\
\text { instructions }\end{array}$ & $\begin{array}{l}\text { Exp } \\
\text { Co } \\
\text { n. }\end{array}$ & $\begin{array}{l}10 . \\
00 \\
10 . \\
37\end{array}$ & $\begin{array}{c}2 . \\
03 \\
1 . \\
38\end{array}$ & $\begin{array}{c}- \\
.61 \\
0\end{array}$ & .547 \\
\hline $\begin{array}{l}\text { Using } \\
\text { motivated } \\
\text { question } \\
\text { techniques }\end{array}$ & $\begin{array}{l}\text { Exp } \\
\text { Co } \\
\text { n. }\end{array}$ & $\begin{array}{l}12 . \\
96 \\
13 . \\
15\end{array}$ & $\begin{array}{l}1 . \\
23 \\
.9 \\
9\end{array}$ & $\begin{array}{c}- \\
47 \\
4\end{array}$ & 639 \\
\hline $\begin{array}{l}\text { Choosing } \\
\text { suitable } \\
\text { techniques } \\
\text { for } \\
\text { correcting } \\
\text { mistakes }\end{array}$ & $\begin{array}{l}\text { Exp } \\
\text { Co } \\
\text { n. }\end{array}$ & $\begin{array}{l}11 . \\
87 \\
12 . \\
18\end{array}$ & $\begin{array}{l}1 . \\
51 \\
1 . \\
49\end{array}$ & $\begin{array}{l}- \\
.58 \\
8\end{array}$ & .561 \\
\hline $\begin{array}{l}\text { Praising the } \\
\text { correct } \\
\text { answers }\end{array}$ & $\begin{array}{l}\text { Exp } \\
\text { Co }\end{array}$ & $\begin{array}{c}6.5 \\
0 \\
5.8\end{array}$ & $\begin{array}{l}1 . \\
27 \\
1 .\end{array}$ & $\begin{array}{c}1.2 \\
9\end{array}$ & .205 \\
\hline $\begin{array}{l}\text { Systematic } \\
\text { handling of } \\
\text { the } \\
\text { blackboard }\end{array}$ & $\begin{array}{l}\text { Exp } \\
\text { Co } \\
\text { n. }\end{array}$ & $\begin{array}{l}11 . \\
56 \\
11 . \\
25\end{array}$ & $\begin{array}{l}1 . \\
12 \\
1 . \\
22\end{array}$ & $\begin{array}{c}.75 \\
2\end{array}$ & .458 \\
\hline $\begin{array}{l}\text { Making and } \\
\text { using } \\
\text { available } \\
\text { audio-visual } \\
\text { aids }\end{array}$ & $\begin{array}{l}\text { Exp } \\
\text { Co } \\
\text { n. }\end{array}$ & $\begin{array}{c}8.4 \\
0 \\
8.1 \\
8\end{array}$ & $\begin{array}{l}.6 \\
6 \\
.7 \\
7\end{array}$ & $\begin{array}{c}.85 \\
9\end{array}$ & .397 \\
\hline
\end{tabular}

A closer look at table (7), the t-values revealed that no statistically significant differences at $\mathrm{p}<.01$ were found between the 
significant differences at 0.01 level between the mean scores of the control and experimental groups in the post test of classroom performance on the analytic scoring rubric, in favor of the experimental group".

\section{b. Results of the six cores of classroom performance}

Table (9) reports data collected to determine if there were statistically significant differences at $\mathrm{p}<0.01$ between the mean scores of the control and experimental groups in the posttest of classroom performance on each of the six areas of scoring rubric criteria i. e., giving effective instructions, using motivated question techniques, choosing suitable techniques for correcting mistakes, praising the correct answers, systematic handling of the blackboard, and making and using available audio-visual aids. Independent samples t-test was applied. The mean scores, standard deviations, t-values, and $\mathrm{t}$ significance of the six cores of classroom performance for the two groups on the post-test are demonstrated in the table below.

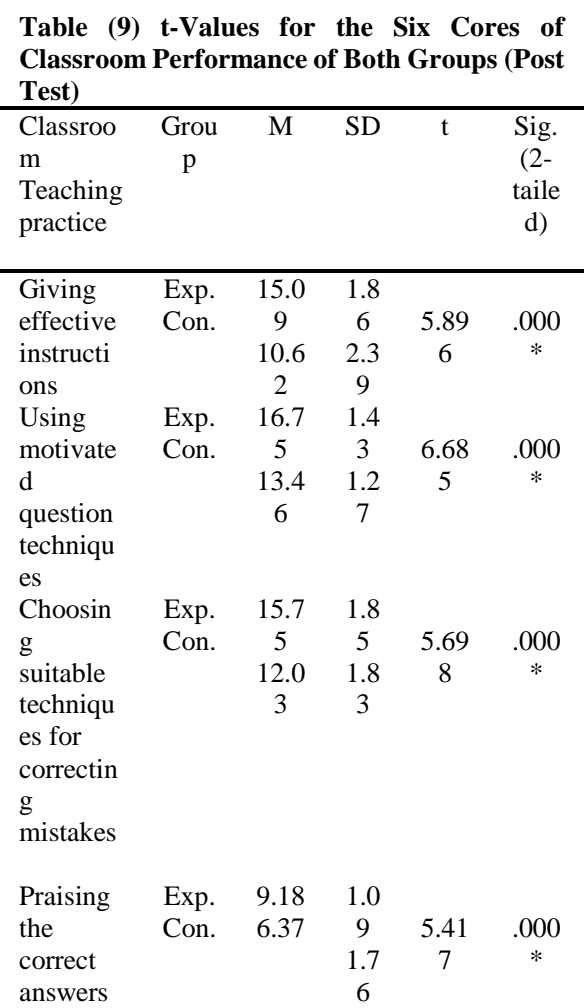

3- Results of the post test for both groups (experimental and control).

\section{a. Results of overall classroom performance}

Independent sample t-test was conducted to compare the gain scores of the experimental group and those of the control group. Table (8) presents the mean scores, standard deviations, $\mathrm{t}$-value, and $\mathrm{t}$ significance of overall classroom performance of the two groups on the post test.

Table (8) t-Value for Overall Classroom Performance of Both Groups (Post Test)

\begin{tabular}{|c|c|c|c|c|c|}
\hline Variable & $\begin{array}{l}\text { Gro } \\
\text { up }\end{array}$ & M & SD & $\mathrm{t}$ & $\begin{array}{l}\text { Sig. } \\
\text { (2- } \\
\text { taile } \\
\text { d) }\end{array}$ \\
\hline & Exp. & 80.4 & 6.9 & & \\
\hline Overall & & 0 & 0 & 7.10 & .000 \\
\hline Classroo & & & & 2 & $*$ \\
\hline & Con. & 62.5 & 7.2 & & \\
\hline $\begin{array}{l}\text { Performa } \\
\text { nce }\end{array}$ & & 9 & 7 & & \\
\hline
\end{tabular}

Table (8) displays that while the mean score of the experimental was 80.40 with a standard deviation of 6.90 , the mean score of the control group was 62.59 with a standard deviation of 7.27. Result of the t-test revealed that there were statistically significant differences at $p<0.01$ between the mean scores of the control and experimental groups in the post test of classroom performance. This means that the experimental group achieved significantly higher degree of improvement than the control group. Figure (3) illustrates the result of table (8).

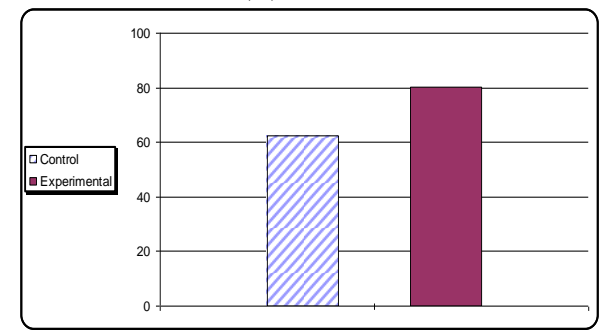

Figure (3) Comparison between scores of both groups in overall classroom performance (post- test)

These findings support the validity of the first hypothesis of the study "There are statistically 
level between the mean scores of the control and experimental groups in the post-test of classroom performance on each of the six areas of analytic scoring rubric criteria i. e., giving effective instructions, using motivated question techniques, choosing suitable techniques for correcting mistakes, praising the correct answers, systematic handling of the blackboard, and making and using available audio-visual aids., in favor of the experimental group" was confirmed. Figure (4) illustrates the results of table (9).

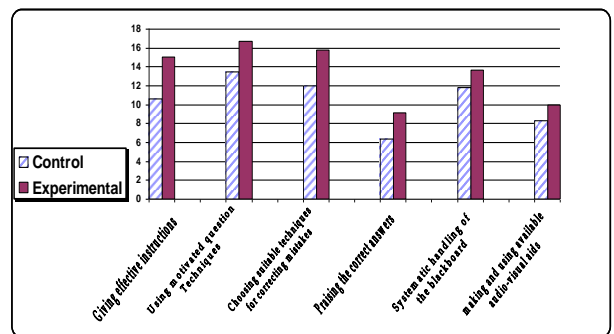

Figure (4) Comparison between scores of both groups on the six cores of classroom performance (post-test)

4-Results of the pre-post-test for the experimental group.

a. Results of overall classroom performance.

Paired samples t-test was applied to determine if there were statistically significant differences at $\mathrm{p}<0.01$ among the experimental group's means of scores in the pre and post-test of classroom performance on the analytic scoring rubric. Table (10) demonstrates the mean scores, standard deviations, t-value, and significance of overall classroom performance of the experimental group in the pre and post-test.

Table (10) $t$-Value for Overall Classroom Performance of the Experimental Group (Pre-Post Test)

\begin{tabular}{|c|c|c|c|c|c|}
\hline $\begin{array}{c}\text { Variabl } \\
\mathrm{e}\end{array}$ & $\begin{array}{c}\text { Measure } \\
\text { ment }\end{array}$ & $\mathrm{M}$ & $\begin{array}{l}\mathrm{S} \\
\mathrm{D}\end{array}$ & $\mathrm{t}$ & $\begin{array}{c}\text { Sig. } \\
(2- \\
\text { tail } \\
\text { ed) }\end{array}$ \\
\hline Overall & Pre & 61. & 5. & & \\
\hline Classro & & 31 & 67 & - & .00 \\
\hline om & Post & 80. & 6. & 9.2 & $0 *$ \\
\hline Perform & & 40 & 90 & 91 & \\
\hline
\end{tabular}

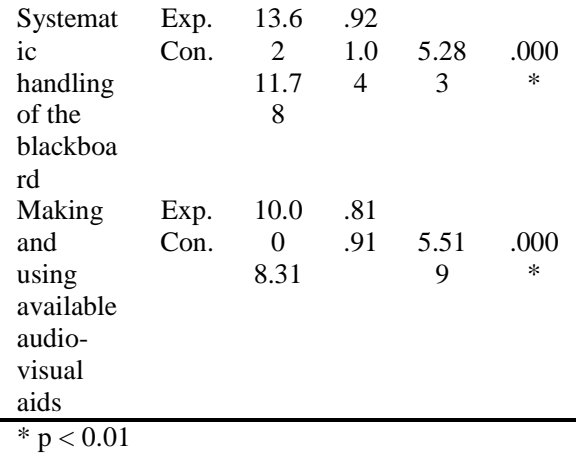

The $\mathrm{t}$-values revealed that there were statistically significant differences at $p<0.01$ between the mean scores of the control and experimental groups in the posttest of classroom performance on each of the six areas of scoring rubric criteria i. e., giving effective instructions, using motivated question techniques, choosing suitable techniques for correcting mistakes, praising the correct answers, systematic handling of the blackboard, and making and using available audio-visual aids. Results indicated that the reflective group performed better than the unreflective group on the six cores of classroom performance. For the experimental group, the subjects scored (15.09), (16.75), (15.75), (9.18), (13.62), (10.00) for giving effective instructions, using motivated question techniques, choosing suitable techniques for correcting mistakes, praising the correct answers, systematic handling of the blackboard, and making and using available audiovisual aids, respectively. Concerning the control group, the subjects scored (10.62), (13.46), (12.03), (6.37), (11.78), (8.31) for giving effective instructions, using motivated question techniques, choosing suitable techniques for correcting mistakes, praising the correct answers, systematic handling of the blackboard, and making and using available audiovisual aids, respectively. Based on these results, the second hypothesis "There are statistically significant differences at 0.01 
motivated question techniques, choosing suitable techniques for correcting mistakes, praising the correct answers, systematic handling of the blackboard, and making and using available audiovisual aids. Table (11) presents the mean scores, standard deviations, tvalues, and $t$ significance of the six cores of classroom performance, for the experimental group on the pre and post-test.

Table (11) $t$-Values for the Six Cores of Classroom Performance of the Experimental Group (Pre-Post Test)

\begin{tabular}{lcclcl}
\hline Classroo & Measure & M & S & t & Sig \\
$\mathrm{m}$ & ment & & D & & $(2-$ \\
Teachin & & & & & tail \\
$\mathrm{g}$ & & & & & ed $)$ \\
Practice & & & & &
\end{tabular}

\begin{tabular}{lccccc}
\hline Giving & Pre & 10. & 2. & & \\
effective & Post & 00 & 03 & - & .00 \\
instructi & & 15. & 1. & 7.246 & $0 *$ \\
ons & & 09 & 86 & & \\
& & & & & \\
Using & Pre & 12. & 1. & & \\
motivate & Post & 96 & 23 & - & .00 \\
d & & 16. & 1. & 7.027 & $0 *$ \\
question & & 75 & 43 & & \\
techniqu & & & & & \\
es & & & & & \\
& & & & & \\
Choosin & & & & & \\
g & Pre & 11. & 1. & & .00 \\
suitable & Post. & 87 & 51 & - & \\
techniqu & & 15. & 1. & 7.766 & $0 *$ \\
es for & & 75 & 85 & & \\
correcti & & & & & \\
ng & & & & & \\
mistakes & & & & &
\end{tabular}

$\begin{array}{lccccc}\text { Praising } & \text { Pre } & 6.5 & 1 . & & \\ \text { the } & \text { Post } & 0 & 27 & - & .00 \\ \text { correct } & & 9.1 & 1 . & 5.805 & 0^{*} \\ \text { answers } & & 8 & 09 & & \end{array}$

$\begin{array}{lccccc}\text { Systema } & \text { Pre } & 11 . & 1 . & & \\ \text { tic } & \text { Post } & 56 & 12 & - & .00 \\ \text { handling } & & 13 . & .9 & 6.822 & 0^{*} \\ \text { of the } & & 62 & 2 & & \\ \begin{array}{l}\text { blackbo } \\ \text { ard }\end{array} & & & & & \\ \text { Making } & \text { Pre } & 8.4 & .6 & & \\ \begin{array}{l}\text { and } \\ \text { using }\end{array} & \text { Post } & 0 & 6 & - & .00 \\ \text { availabl } & & 10 . & .8 & 6.352 & 0^{*} \\ \text { e audio- } & & 00 & 1 & & \\ \text { visual } & & & & & \\ \text { aids } & & & & & \\ * \text { p }<0.01 & & & & \\ \end{array}$

that there were statistically significant differences at $p<0.01$ among the experimental group's means of scores in the pre and post-test of classroom performance ance

$* \mathrm{p}<0.01$

The previous table (10) shows clearly that a remarkable gain occurred to the mean score of the experimental group's overall classroom performance in the posttest. Means differences between the pre and post-test of the experimental group were computed. As presented in table 4.6, the mean scores were 61.31 and 80.40 with standard deviations of 5.67 and 6.90 for the pre and post-test, respectively. The obtained t-value (-9.29) revealed that statistically significant differences were found at $p<0.01$ among the experimental group's means of scores in the pre and post- test of classroom performance on the analytic scoring rubric, in favor of the posttest. Thus, the third hypothesis "There are statistically significant differences at 0.01 level among the experimental group's means of scores in the pre and post-test of classroom performance on the analytic scoring rubric, in favor of the post-test" was accepted. The following figure illustrates the result of table (10).

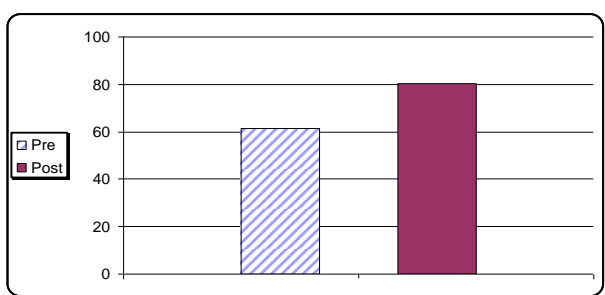

Figure (5) Comparison between pre and post scores of overall classroom performance for the experimental group

\section{b- Results of the six cores of classroom performance}

Paired samples t-test was applied to determine if there were statistically significant differences at $\mathrm{p}<0.01$ among the experimental group's means of scores in the pre and post-test of classroom performance on each of the six areas of scoring rubric criteria i. e., giving effective instructions, using 
(6) illustrates the results of table (11).

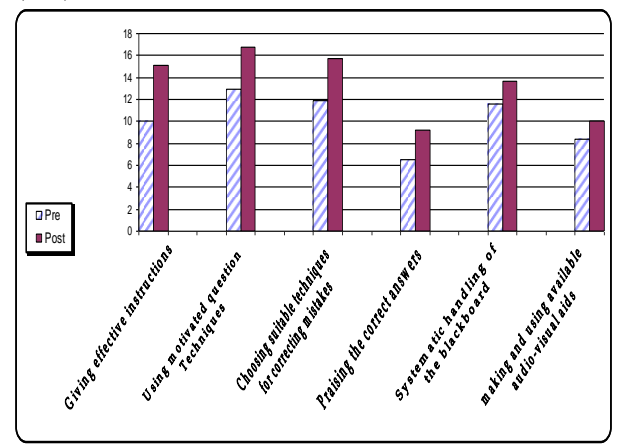

Figure (6) Comparison between pre and post scores of the experimental group on the six cores of classroom performance

5- The effect size of using the reflective teaching approach on overall classroom performance

To measure the effect size "d" of using the reflective teaching approach (independent variable) on the classroom performance (dependent variable) of the subjects (experimental group), Eta Squared $" \eta^{2}$ " was computed using " $t "$ value for the differences between the means (Kiess, 2002, p.203):

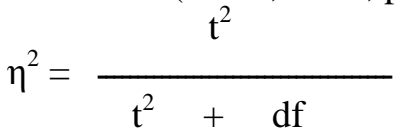

Thus, " $\eta^{2} "$ value was 0.85 . Depending on " $\eta^{2} "$ value, the effect size " d " was computed using the following statistical formula.

$\mathrm{d}=\frac{\sqrt{\eta^{2}}}{\sqrt[2]{1-\eta^{2}}}$

Thus, the effect size "d" was 4.76

The effect size is identified whether it is large, medium, or small according to the following (Howell, 2007, p. 217):

\begin{tabular}{cc}
\hline$" \mathrm{~d} "$ & Small \\
value $=$ & \\
0.2 & \\
$" \mathrm{~d} "$ & Medium \\
value $=$ & \\
0.5 & \\
$" \mathrm{~d} "$ & Large \\
value $=$ & \\
0.8 & \\
\hline
\end{tabular}

on each of the six areas of scoring rubric criteria i. e., giving effective instructions, using motivated question techniques, choosing suitable techniques for correcting mistakes, praising the correct answers, systematic handling of the blackboard, and making and using available audio-visual aids. The above table shows that the experimental group's mean scores in the pre-test of the six cores of classroom performance were lower than those obtained in the post test. Regarding giving effective instructions, using motivated question techniques, choosing suitable techniques for correcting mistakes, praising the correct answers, systematic handling of the blackboard, and making and using available audio-visual aids, the experimental group got (15.09), (16.75), (15.75), (9.18), (13.62), (10.00), respectively in the post test. On the contrary, the same group scored (10.00), (12.96), (11.87), (6.50), (11.56), (8.40) for giving effective instructions, using motivated question techniques, choosing suitable techniques for correcting mistakes, praising the correct answers, systematic handling of the blackboard, and making and using available audiovisual aids, respectively in the pretest. Based on these results, the fourth hypothesis of the study "There are statistically significant differences at 0.01 level among the experimental group's means of scores in the pre and post-test of classroom performance on each of the six areas of analytic scoring rubric criteria i. e., giving effective instructions, using motivated question techniques, choosing suitable techniques for correcting mistakes, praising the correct answers, systematic handling of the blackboard, and making and using available audio-visual aids, in favor of the post-test" was supported. Figure 


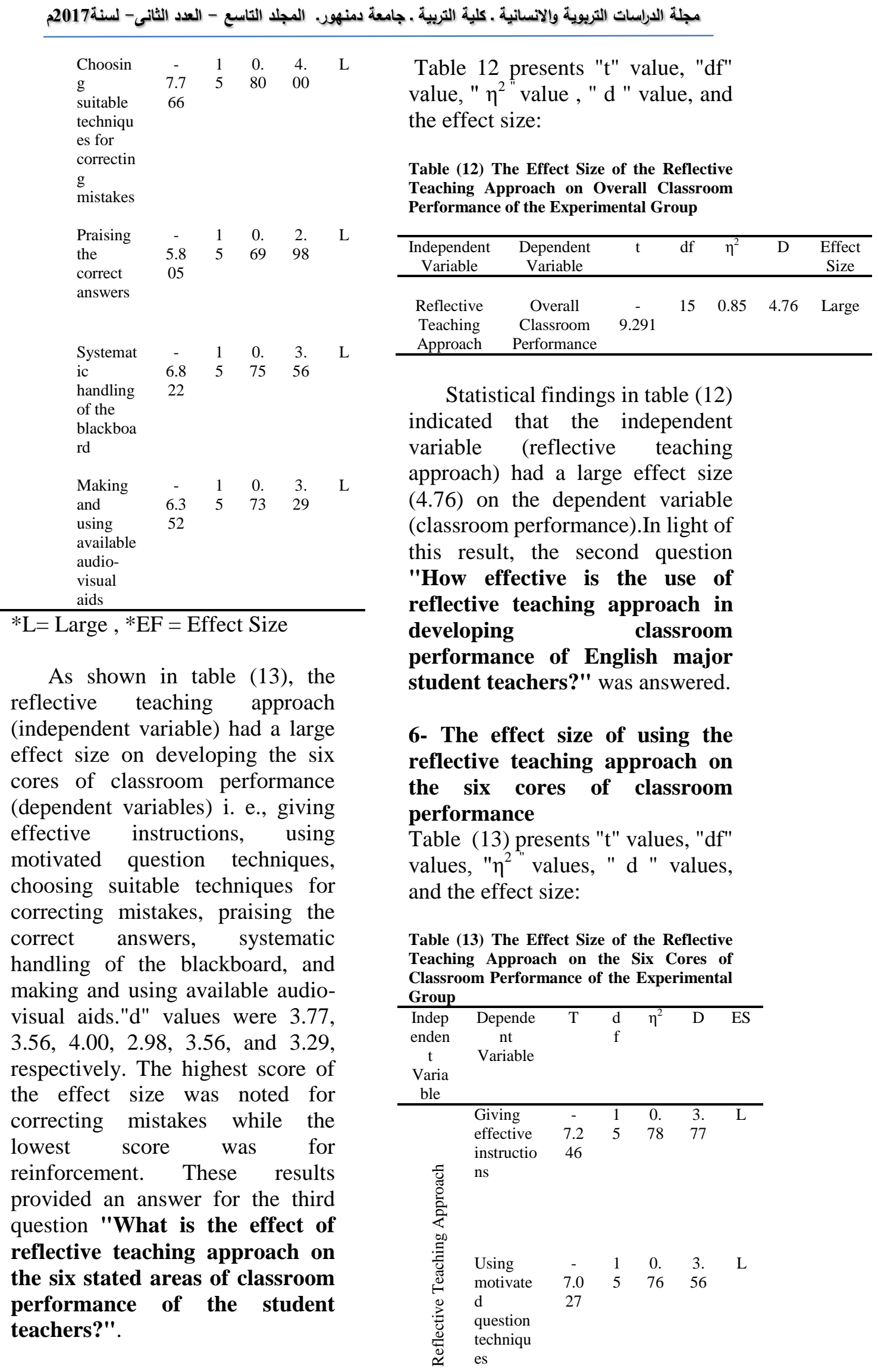

7- Results of the questionnaire on attitudes towards reflective teaching practices (QARTP).

Table (14) presents descriptive statistics i. e., mean, standard deviation and percentage of total 


\begin{tabular}{|c|c|c|c|c|c|c|}
\hline $\begin{array}{l}\text { 4- I wish every teacher } \\
\text { would use this } \\
\text { approach. }\end{array}$ & 9 & 5 & 1 & 1 & 0 & $\begin{array}{c}87 . \\
5\end{array}$ \\
\hline $\begin{array}{l}\text { 5- Reflective teaching } \\
\text { is not important. }\end{array}$ & 0 & 0 & 1 & 9 & 6 & $\begin{array}{l}93 . \\
57\end{array}$ \\
\hline $\begin{array}{l}\text { 6- I would like to be a } \\
\text { powerful model of the } \\
\text { reflective practitioner } \\
\text { in the future. }\end{array}$ & 8 & 5 & 5 & 0 & 0 & $\begin{array}{l}81 . \\
25\end{array}$ \\
\hline $\begin{array}{l}\text { 7- The reflective } \\
\text { teaching approach } \\
\text { makes me feel tense } \\
\text { and uncomfortable. }\end{array}$ & 0 & 1 & 0 & 7 & 6 & $\begin{array}{l}81 . \\
25\end{array}$ \\
\hline $\begin{array}{l}\text { 8- I am satisfied of } \\
\text { using reflective } \\
\text { teaching. }\end{array}$ & 11 & 5 & & 0 & 0 & $\begin{array}{c}10 \\
0\end{array}$ \\
\hline $\begin{array}{l}\text { 9- Reflective teaching } \\
\text { experience is } \\
\text { enjoyable. }\end{array}$ & 11 & 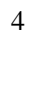 & & 1 & 0 & $\begin{array}{r}93 . \\
75\end{array}$ \\
\hline $\begin{array}{l}\text { 10- Reflecting on } \\
\text { teaching practices } \\
\text { reveals a sense of } \\
\text { responsibility for } \\
\text { learning and teaching } \\
\text { change. } \\
\text { II- Journal Writing }\end{array}$ & 7 & 9 & & 0 & 0 & $\begin{array}{c}10 \\
0\end{array}$ \\
\hline $\begin{array}{l}11 \text { - Using reflective } \\
\text { journal is a waste of } \\
\text { time. }\end{array}$ & 1 & 1 & 4 & 5 & 5 & $\begin{array}{c}62 . \\
5\end{array}$ \\
\hline $12-\mathrm{JW}$ is useful for & 1 & 4 & U & 1 & 0 & 93 \\
\hline $\begin{array}{l}\text { improving teaching } \\
\text { skills. }\end{array}$ & 1 & & & & & 75 \\
\hline $\begin{array}{l}\text { 13- The use of journals } \\
\text { makes it possible to give } \\
\text { honest reactions to } \\
\text { classroom events. }\end{array}$ & 4 & 0 & & 0 & 0 & 87. \\
\hline $\begin{array}{l}\text { 14- JW helps in } \\
\text { assessing teaching } \\
\text { problems. }\end{array}$ & 8 & + & & 0 & 0 & 75 \\
\hline
\end{tabular}

Table (15) (continued)

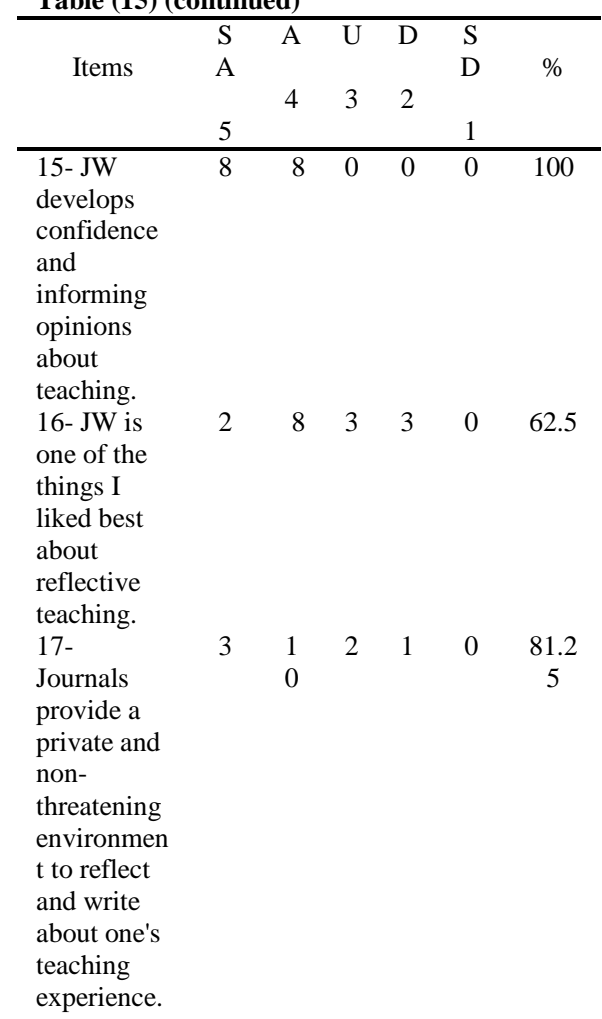

scores obtained by the experimental group.

Table (14) Mean, Standard Deviation, and Percentage of the Experimental Group's Scores in the (QARTP)

\begin{tabular}{cccc}
\hline Group & Mean & SD & $\%$ \\
& Response & & \\
s & & \\
\hline $\begin{array}{c}\text { Experimenta } \\
1\end{array}$ & 134.93 & 13.7 & 84.3 \\
& & 8 & 3 \\
\hline
\end{tabular}

* Total possible score is 160 points

As shown in the above table, the mean of the total subjects' scores in the questionnairewas 134,93 with a standard deviation of 13.78 . The percentage of responses to the statements of the questionnaire was high (84.33 $\%)$. These results implied that the experimental group had favorable attitudes towards reflective teaching practices. Thus, the fourth question "What are the experimental group's attitudes towards reflective teaching practices?" was answered and the fifth hypothesis of the study "There are favorable attitudes among the experimental group's towards reflective teaching practices" was accepted.

The quantitative data gathered were tabulated and analyzed statistically using frequency of responses and percentages. Results of the questionnaire are reported in detail in table (15).

Table (15) Frequency and Percentages of the Experimental Group's Responses on (QARTP)

\begin{tabular}{|c|c|c|c|c|c|c|}
\hline Items & $\begin{array}{l}\mathrm{S} \\
\mathrm{A}\end{array}$ & $\mathrm{A}$ & $\bar{U}$ & $\begin{array}{l}\mathrm{D} \\
2\end{array}$ & $\begin{array}{l}\mathrm{S} \\
\mathrm{D}\end{array}$ & $\%$ \\
\hline \multicolumn{7}{|c|}{ I- Reflective Teaching Approach } \\
\hline $\begin{array}{l}\text { 1- Reflective teaching } \\
\text { is helpful. }\end{array}$ & 11 & 5 & 0 & 0 & 0 & $\begin{array}{c}10 \\
0\end{array}$ \\
\hline $\begin{array}{l}\text { 2- I wish I was } \\
\text { introduced to reflective } \\
\text { teaching and its } \\
\text { principles in EFL } \\
\text { methodology course. }\end{array}$ & 3 & $\begin{array}{l}1 \\
0\end{array}$ & 3 & 0 & 0 & $\begin{array}{l}81 . \\
25\end{array}$ \\
\hline $\begin{array}{l}\text { 3- I will make every } \\
\text { effort to learn more } \\
\text { about reflective } \\
\text { teaching. }\end{array}$ & 7 & 9 & 0 & 0 & 0 & $\begin{array}{c}10 \\
0\end{array}$ \\
\hline
\end{tabular}




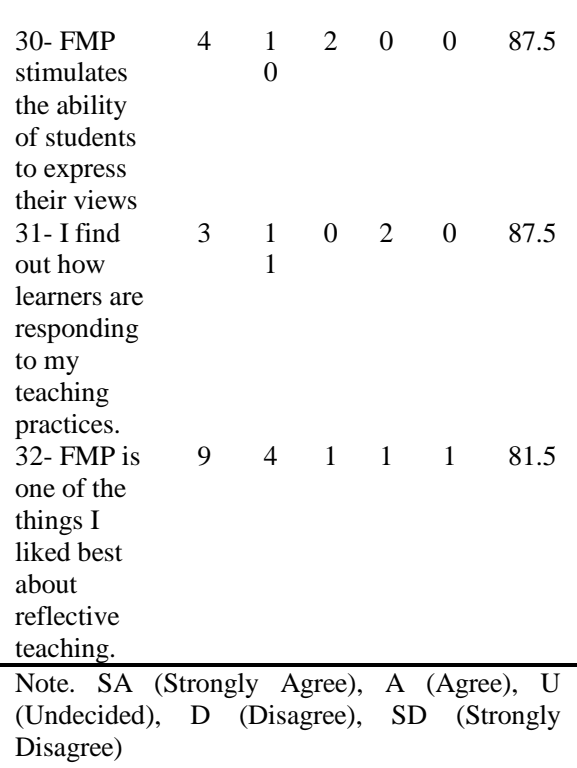

Data collected showed that allthe subjects $(100 \%)$ agree that thereflective teaching is helpfuland it reveals a sense of responsibility for learning and teaching change. Also, theyare satisfied of using reflective teaching and they are willing to make every effort to learn more about reflective teaching (see items 1, 3, 8, and 10). Eighty one per cent of the sample wish that they were introduced to reflective teaching and its principles in EFL methodology course and they would like to be a powerful model of the reflective practitioner in the future (see item 2 and 6). Most of them (93.75\%) believe that the reflective teaching experience is enjoyable (see item $9)$, whereas $(87.5 \%)$ wish every teacher would use this approach (see item 4). On the other hand, $(93.75 \%)$ disagree that reflective teaching is not important (see item5). Eighty one per cent of the sample refuse that they feel tense and uncomfortable when using the reflective teaching approach (see item 7).

Regarding journal writing, the subjects $(100 \%)$ assure that journal writing develops confidence and informing opinions about teaching and it is good for achieving goals (see items 15 and $19)$, whereas $(93.75 \%)$ maintain

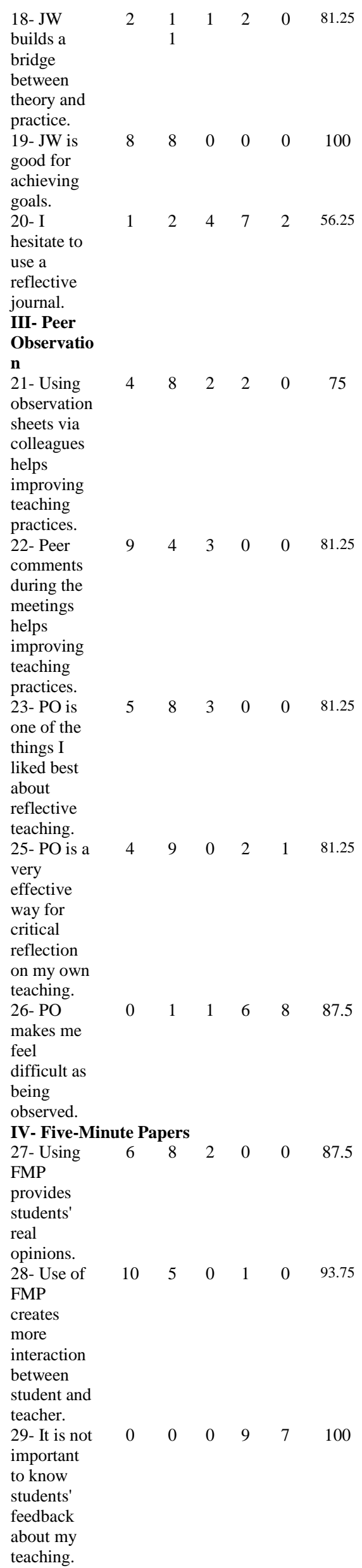


perceiving and responding to their teaching practices (see items 27, 30, and 31). Most of them $(93.75 \%)$ confirm that the use of five-minute papers creates more interaction between student and teacher (see item 28). Only $(81.5 \%)$ think that five-minute papers is one of the things they liked best about reflective teaching (see item 32). Clearly, allthe subjects $(100 \%)$ disagree that it is not important to know students feedback about their teaching (see item 29).

\section{- Discussion and Interpretation of the Results}

The following discussion can be stated in light of the present study results, review of literature, and the previous related studies.

It is clear from the results that the most important classroom teaching practices for which both groups need the greatest help were "giving instructions, questioning techniques, correcting mistakes, reinforcement, handling the blackboard, and making and using of audio-visuals aids". Conversely, the items which got the lowest frequency and percentage were "use of students' names", "student grouping", "dealing with students problem", "rapport with students", "use of resources", and "use of Arabic", respectively. In addition, "timing of class", "explanations/ discussion of rules", and "practicing new language patterns and structures" had similar frequency and percentage.

Results indicated that the experimental group outperformed the control group in classroom teaching practices. The high scores obtained by the experimental group on the post test was due to the large effect of reflective approach on classroom performance. The experimental group showed a satisfactory improvement with reference to classroom teaching practices i. e., giving instructions, that it is useful for improving teaching skills (see item 12). Most of them $(87.5 \%)$ agree that the use of journals makes it possible to give honest reactions to classroom events (see item 13). Only (62.5\%) of the subjects express that journal writing is one of the things they liked best about reflective teaching (see item 16). Although (81.25\%) assert that journals provide a private and non-threatening environment to reflect and write about one's teaching experience and builds a bridge between theory and practice (see items 17 and 18), seventy five per cent think that it helps in assessing teaching problems (see item 14). However, $(62.5 \%)$ disagree that using reflective journal is a waste of time (see item 11). Others $(56.25 \%$ ) assure that they do not hesitate to use the reflective journal (see item 20).

As for peer observation, (75 $\%)$ of the subjects agree that the use of observation sheets via colleagues helps improving teaching practices (see item 21) whereas $(87.5 \%)$ believe that peer observation provides opportunities to view each other's teaching by exposing to different teaching styles (see items 24). Moreover, $(81.25 \%)$ indicate that peer comments during the meetings helps improving teaching practices and a very effective way for critical reflection on their own teaching (see items 22, 25). Eighty one per cent of the sample agree that peer observation is one of the things they liked best about reflective teaching (see item 23) while $(87.5 \%)$ disagree that it makes them feel difficult as being observed (see item 26).

As shown in table (15), (87.5\%) of the subjects agree that the use of five-minute papers provides students' real opinions and stimulates their ability to express their views. Further, it is a way of finding out how learners are 
that there was a positive attitude towards using reflective teaching approach. Likewise, El-Dib (1993) mentioned that student teachers who adopt the model of reflective teaching are encouraged to adopt a positive attitude toward their practices. This finding goes in line with what was arrived at in a treatment done by Redmon (2004) that participants were uniformly positive about the experience and indicated a feeling that they had learned both from reflective process and from each other. $\mathrm{He}$ added that e-mail discussion groups do seem to engender a collaborative attitude and mutual support on the part of the participants.

The experimental group responses on the feedback questionnaire also showed favorable attitudes towards using the reflective teaching activities. They perceived the reflective model to be successful. It helped them to be successful teachers. Evidence in support of this view could be found in McCollum (1997) who reported the preservice teachers' views on the value of guided reflection and how they perceived reflection as meaningful for their professional growth and development as prospective teachers. Fulmer (1993) added that the learning process in reflective practice begins with the examination of an individual's own actions and contrasting the actions to the ideal of the practice. This process results in behavioral changes that improve professional performance. Also, AbouHadid (2004) found that the experimental group (prospective teachers) levels of reflective thinking could be developed. Results of the present study are consistent with some views reported by Shin (2003) who assured that professional development of prospective teachers could happen through reflective teaching and Lange questioning techniques, correcting mistakes, reinforcement, handling the blackboard, and making and using audio-visuals aids. Results also indicated that the experimental group achieved more improvement regarding questioning techniques while they achieved less in reinforcement.

Supporting the above mentioned findings, Pacheco (2005) assured that "reflective teaching is undoubtedly a valid means towards effective teaching practices"(p.12). Baksh (2003) concluded that there were significant differences in the performance of two groups in favor of the experimental group in all seven cases of the suggested reflective model and in the total score. Redmon's (2004) results were also consistent with those of the present study where truly reflexive teachers approach teaching and the teaching profession in a more thoughtful and collegial way. Also, El-Saey (2005) assured that reflective teaching had a positive effect on developing EFL student teachers' teaching skills. Pollard et al. (2002) reported that reflective practice supports initial training students in satisfying performance standards and competences. Reflective teaching is beneficial for both preservice and in-service teachers and teacher education programs are becoming more devoted to develop reflective practices in their student teachers (Pacheco, 2005). Rashed and Mahmoud (2003) also noticed the positive effect of using reflective practice on the student teachers' performance in the practicum program.

Results of the present study indicated that the experimental group had favorable attitudes towards using the reflective teaching approach. This result is in agreement with some other researchers. Baksh (2003) found 
elements of the reflective teacher's practice

Responses on the questionnaire also indicated that using observation sheets via colleagues help improving teaching practices. It is a very effective way for critical reflection on their own teaching. This result is in agreement with Richards (1991) who mentioned that the participants in his project reported a number of insightful gains about their own teaching from their colleagues' observations and they would like to change as a result of the information their partner collected. Results of the present study are also consistent with those reported in other studies. El-Saey (2005) reported that peers discussions provided student teachers with various opportunities to relate their experience to those of others. Wallace (2004) pointed out that peer observation enabled teachers to get feedback from their colleagues, which was motivating and rewarding, enhancing reflection, improving self-esteem, and relieving tension.

Most of the sample indicated that peer comments during the meetings helps improving teaching practices and a very effective way for critical reflection on their own teaching. This finding goes in line with what was concluded by Bain et al. (1999) that discussion with another person is a powerful strategy for fostering reflective action. Peer observation is a positive solution to some of the problems of traditional in-service affairs that have been used to educate teachers (Galbraith \&Anstrom, 1995). According to Meyer and Gray (1996), teachers report that peer observation is effective in helping them meet their goals. Hoy, Haunum, Moran, and Schannen (1998) reported that when teachers are supported by their peers as well as their principals, they are likely to take
(1990) who proved that there is an intimate relationship between reflective teaching and teacher development.

Results of the questionnaire indicated that the majority of the experimental group agrees that journal writing is useful for improving teaching skills and assessing teaching problems. This result is in harmony with Thomas (2003) who stated that the students could make positive changes in their learning by using the logs (journals) to focus, reflect and work out problems and stumbling blocks on their own. Bain et al. (1999) also confirmed that students come to the journal writing task with a wide range of reflective skills and attitudes. This finding goes in line with what was provided by Porter, Goldstein, Leatherman, and Conrad (1990) and Rhodes and Christian (1993) that journals have served as an outlet for reflection and a window on teacher candidates' professional growth as teachers.

Results of Hanna's (1991) study showed that student teachers who were exposed to the awareness techniques (using observation sheet) came closer to the researcher's own evaluation than did the control group. Most of the sample agreed that Journals provide a private and nonthreatening environment to reflect and write about one's teaching experience. This result is consistent with some studies that concentrated on the potential benefits of using teaching and learning journals as tool for self-reflection by students in teacher education programs (e.g., Dant, Boulton-Lewis, Brwonlee\&McCrindle, $\quad$ 1998; Halbach, 1999; Crandall, 2000).Also, this result is in harmony with Sparks-Langer and Colton (1991) who believed that reflective journals are often key 
classroom performance i. e., giving effective instructions, using motivated question techniques, choosing suitable techniques for correcting mistakes, praising the correct answers, systematic handling of the blackboard, and making and using available audiovisual aids. So, the second and third questions were answered.

3- Statistically significant differences were found in overall classroom performance in favor of the experimental group as compared with the control group, due to reflective teaching practices ( $\mathrm{t}$-value is 7.10). Thus, the first hypothesis was accepted.

4- Statistically significant differences were noted for classroom teaching practices, in favor of the experimental group, in the post-test. The experimental group gained higher scores than the control one on each of six cores of classroom performance i. e., giving effective instructions, using motivated question techniques, choosing suitable techniques for correcting mistakes, praising the correct answers, systematic handling of the blackboard, and making and using available audiovisual aids (t-values are 5.89, $6.68,5.69,5.41,5.28$, and 5.51 , respectively). Thus, the second hypothesis was confirmed.

5- Statistically significant differences were found among the mean scores of the experimental group in the pre and post-test of overall classroom performance, in favor of the post-test ( $t$-value is -9.29). So, the third hypothesis was supported.

6- There were statistically significant differences among the mean scores of the experimental group in the pre and post-test on each of six greater risks to improve their instruction, remain in the teaching and show more interest in building activities and goals.

The experimental group agrees that the five-minute papers create more interaction between student and teacher. Learners' feedback is viewed as a way of finding out how learners are perceiving and responding to their teaching practices. These results go with those reported in some other related studies (Draper, 2006 \& Cobb, n.d)and Wilson (1986) who assured that it is a powerful assessment tool for continuous improvement of a class. The studies demonstrated that the benefit of five-minute paper is to get good feedback from learners to teacher on how learning and teaching process is going and to discover how well new material presented during a teaching session has been comprehended by learners. Most of the experimental group choose peer observation and five-minute papers as things they liked best about reflective teaching but a few of them choose journal writing.

\section{- Results of the study}

The following results were derived from the analysis of data:

1- The most important classroom teaching practices in which both groups need the greatest help "were giving effective instructions, using motivated question techniques, choosing suitable techniques for correcting mistakes, praising the correct answers, systematic handling of the blackboard, and making and using available audio-visual aids". Thus, the first question was answered.

2- The reflective teaching approach had a large effect on overall classroom performance of the experimental group and on each of six cores of 
teachers and what happened inside the classroom.

8- It is necessary find out the effect of using reflection on several aspects of student teachers such as personal feature and performance as a whole (inside and outside the classroom).

- Suggestions for Further Research :

1- This study can be replicated on other classroom teaching practices (e. g., timing of class, posture and movement, use of Arabic, use of voice, student grouping, classroom management, and practicing new language patterns and structures).

2- There is a need to further research other reflective tools i. e., portfolio, computer conferencing, action research, and videotaping that can be employed by EFL teachers.

3- There is a need for further exploration of differences in attitudes to reflection and reflective practice.

4- A study comparing the effects of different reflective teaching practices (journal writing, peer observation, fiveminute papers) on teacher development. cores of classroom performance i. e., giving effective instructions, using motivated question techniques, choosing suitable techniques for correcting mistakes, praising the correct answers, systematic handling of the blackboard, and making and using available audio-visual aids (t-values are -7.24, -7.02, $7.76,-5.80,-6.82$, and -6.35 , respectively), in favor of the post-test. Thus, the fourth hypothesis was accepted.

7- There were favorable attitudes among the experimental group towards using reflective teaching activities. So, the fifth hypothesis was proved and the fourth question was answered.

\section{- Recommendations :}

In view of the findings and conclusions of this study, the following recommendations are presented:

1- The reflective teaching approach should be incorporated in EFL teacher education programs.

2- Student teachers should be introduced to reflective teaching and its principles in EFL methodology course.

3- Student teachers should make every effort to learn more about reflective teaching and its activities.

4- Student teachers should improve their effectiveness in the classroom by gaining a better understanding of their own individual teaching styles through reflective practice.

5- Prospective teachers should be trained on methods of developing reflective thinking levels.

6- It is recommended to offer student teachers the opportunity to work with peers.

7- Learners at schools should be motivated and encouraged to give their opinions about their 
teach. In J. Calderhead (Ed.), Teachers' professional learning, (pp. 51-64), Philadelphia: The Falmer Press.

Calderhead, J., \& Gates, P. (1993). Introduction. In J. Calderhead\& P. Gates (Eds.), Conceptualizing reflection in teacher development (pp. 1-10). London: The Falmer Press.

Cruickshank, D. R., \& Applegate (1981). Reflective teaching as a strategy for teacher growth. Educational Leadership, 38 (7), 553-554.

El-Dib, M. (1993). Teaching practice : Imprisonment or empowerment. Proceedings of the $12^{\text {th }}$ CDELT National Symposium on English Language Teaching: New Policies and Strategies for English Teaching, Ain Shams University, Cairo, 177-198.

El-Dib, M. (2003). Assessment of reflection in action research. Proceedings of the $2^{\text {nd }}$ CDELT National Symposium on English Language Teaching: The Specific Role of EFL for the Arab World: The Decade Ahead, Ain Shams University, Cairo, 161-182.

El-Sayed, M. A. (2005). The effect of using reflective teaching on developing EFL student teachers' teaching skills (A case study). Unpublished master's thesis, Ain Shams University.

Farrell, T. (1998). Reflectiveteaching: The principles and practices. English Teaching Forum, 36 (4), 10-17.

Finely, F. L., Lawrenz, F. \& Heller, P. (1992). A Summary of research in science education. Science Education, 76 (3), pp. 239338.

Frank, P. (1999). Becoming a reflective teaching. Retrieved
- References :

AbouHadid, A. A. F. (2004). Promoting prospective teachers' reflective thinking levels via the process approach.Occasional Papers in the Development of English Language Education, CDELT, Ain Shams University, Cairo, 37, 157-190.

Aly, M. M. (2004). Supervision in teacher education: A developmental approach for the TEFL teaching practice.Proceedings of the $23^{\text {rd }} \quad$ CDELT National Symposium on English Language Teaching: The Language Education in the Arab World: Guaranteeing an Active Learning Environment, Ain Shams University, Cairo,155-170.

Bain, J., Ballantyne, R., Packer, J., \& Mills, C. (1999). Using journal writing to enhance student teachers' reflectively during field experience placement.Teachers and Teaching: Theory and Practice, 5 (1), 51-73.

Bartlett, L. (1990). Teacher development through reflective teaching. In J. C. Richards \& D. Nunan (Eds.), Second language teacher education (pp. 202-214). Cambridge: Cambridge University Press.

Burden, R., \& Williams, M. (1998). Thinking through the curriculum. New York: Routledge, eBookMall, Inc.

Burge, E. J. (2004). Bridging action and reflection: Strategies and questions for teaching libraries. In D. B. Thomas, R. Tammany, R. Daier, E. Owen, \& H. Mercado (Eds.), Reflective teaching: A bridge to learning (pp. 9-18). Michigan: Pierian Press.

Calderhead, J. (1988). Knowledge structures in learning to 
writing.berkeley.edu/TESI-

EJ/ej24/a2html

McCollum, S. (1997). Insight into

the process of guiding

reflection during an early

field experience of pre-

service teachers.

Unpublished doctoral

dissertation, Faculty of

Virginia: Polytechnic

Institute and State

University.

McIntyre, J., \& O'Hair, M. J. (1996). The reflective roles of the classroom teacher. California: Wadsworth

Miyata, H. (2002). A study of developing reflective practices for preservice teachers through a webbased electronic teaching portfolio and video-ondemand assessment program.Proceedings of Society for Information Technology and Teacher Education International Conference 2002 (pp. 13851389). Chesapeake, VA: AACE

Murphy, J. M. (2001). Reflective teaching in ELT. In M. Celce - Murica (Ed.), Teaching English as a second or foreign language $\left(3^{\text {rd }}\right.$ ed., pp. 499-514). Boston, MA: Heinle\&Heinle.

Neisler, J. (2000). How does teacher education need to change to meet the needs of America's school at the start of the $21^{\text {st }}$ century?. Journal of Teacher Education, 51(3), 248-255.

Opp-Beckman, L. \&Klinghammer, S. (2006). Shaping the way we teach English: successful practices around the world. Washington, DC: The office of English Language Programs, Bureau of Educational and Cultural Affairs.

Posner, G. J. (2005). Field experience: A guide to
June 25, 2007, from http://www.neo.org.teachexp erience/tresk030605.html.

Galanouli, D., \& Collins, J. (2002). Using unmediated computer conferencing to promote reflective practice and confidence-building in initial teacher education. Journal of Information Technology for Teacher Education, 9 (2), 237-254.

Gebhard, J., \&Oprandy, R. (1999). Language teaching awareness: A guide to exploring beliefs and practices. New York: Cambridge University Press. Glowacki-Dudka, M., \& Barnett, N. (2007). Connecting critical reflection and group development in online adult education classrooms.

International Journal of

Teaching and Learning in Higher Education, 19 (1), 43-52.

Hatton, N. \& Smith, D. (1995). Reflection in teacher education: Towards definition and implementation. Teaching and teacher Education, 11 (1), 33-49.

Jokinen, H. \&Saranen, E. (1998). Development of student teachers' self-assessment. Retrieved May 24, 2007, from http://www.jyu.fi/ktl/publicat ions/electronic/001/jokinen.h tm

Lange, D. (1990). A blueprint for a teacher development program. In J. C. Richards \& D. Nunan (Eds.), Second language teacher education (pp. 245-268). Cambridge: Cambridge University Press.

Liaw, M. L. (2001). Cross-cultural e-mail correspondence for reflective EFL teacher education. TESL-EJ, 6 (4). Retrieved May 22, 2007 from http://www- 
V. M. (2003). The evolution of a process portfolio as an assessment system in a teacher education program. Current Issues in Education, 6 (1). Retrieved June 20, 2007, from http://www.cie.asu.edu/volume6/numbe rl/index.html reflective teaching.Boston: Allyn and Bacon.

Redmon, R. D. (2004, February). E-mail reflection groups : Asynchronous, dialectic, reflective journaling as collaborative action research. Paper presented at the annual meeting of the southwest educational research association (SERA), Dallas, Texas.

Richards, J. C. (1990a). Beyond training : Approaches to teacher education in language teaching. Language Teacher, 14 (2), 3-8.

Richards, J. C. (1991). Towards reflective teaching. Retrieved May 22, 2007, from http://www.tttjournal.co.uk/b ack33.htm

Richards, J., \& Lockhart, C. (2005). Reflective teaching in second language classroom. Cambridge: Cambridge University Press.

Ross, D. Bondy, E., \& Kyle, D. (1993). Reflective teaching for student empowerment. New York: Macmillan Publishing Company, Inc.

Schon, D. A. (1987). Educating the reflective practitioner. San Francisco: Josse-Bass.

Shin, S. J. (2003). The reflective L2 writing teacher. ELT Journal, 57 (1), 3-10.

Thomas, H. H. (2003). A case study of reflective journals in a university-level EFL writing course in Hungary. English Teaching Forum, 41 (1), 22-28.

Wallace, M. J. (1991). Training foreign language teachers: A reflective approach. Cambridge : Cambridge University Press.

Ward, J. R. (2004). Reflection as a visible outcome for preservice teachers. Teaching and teacher education, 20 (3), 243-257.

Williams, S. C., Davis, M. L., Metcalf, D. and Covington, 
